\title{
UN SCR 1325 \\ Implementation in Afghanistan
}




\section{The Afghan Women's Network}

The Afghan Women's Network was created after the United Nations Fourth World Conference on Women in Beijing, China. Afghan women living as refugees in Pakistan attended this conference and were inspired to establish a platform where they could share their observaitions and concerns and ways to resolve them. The Afghan Women's Network is a major force in Afghanistan's nascent women's movement and serves as a well-established network of women's organizations operating throughout the country.

Report Author: Zarin Hamid

Researchers: Zarin Hamid, Zamaray Zalmay, Wida Latif

AWN Field Researchers: Organization for Afghanistan Development (OAD), Tolo Services and Cultural Organization (TSCO), Ariamehr Rehabilitation Establishment (ARE), Afghan Women's Rights Organization (AWRO), Afghan Women Association for Rehabilitation and Development (AWARD).

\section{(C) 2011 Afghan Women's Network}

This publication may be redistributed non-commercially in any media, unchanged and in whole, with credit given to AWN and the author. Published by the Afghan Women's Network with support from the European Union in Kabul, Afghanistan.

Toward the publication of this report, AWN gratefully acknowledges the generous support of the EU, AWN partners, AWN members, researchers, who risk their daily lives to work on behalf of women and the improvement of Afghanistan.

We hope this report can serve to stir the conversation on the state of women in Afghanistan. We hope this report encourages policy makers, at the national and international levels, to support the creation of a comprehensive policy toward the promotion and protection of women in a changing Afghanistan. 


\section{TABLE OF CONTENTS}

I. WOMEN, PEACE, AND SECURITY PROFILE

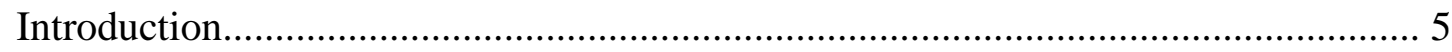

A. NATURE OF THE CONFLICT

1. Country Background on Conflict.............................................................. 5

2. Conflict Actors........................................................................................... 7

B. IMPACT OF CONFLICT ON WOMEN

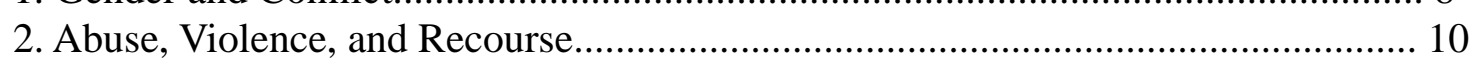

3. Women in Public Space........................................................................................ 12

4. Activism on Women's Rights...................................................................... 12

C. RELEVANT POLICIES AND PRACTICES

1. Afghan Constitution............................................................................... 14

2. Afghan National Development Strategy (ANDS)............................................. 14

3. National Action Plan for Women of Afghanistan (NAPWA) ............................... 15

4. Customary Codes and Practices........................................................................... 16

II. DATA PRESENTATION AND ANALYSIS

\section{A. PARTICIPATION}

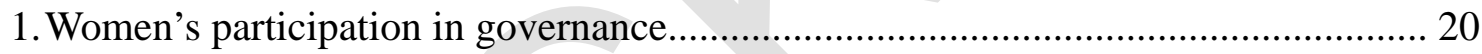

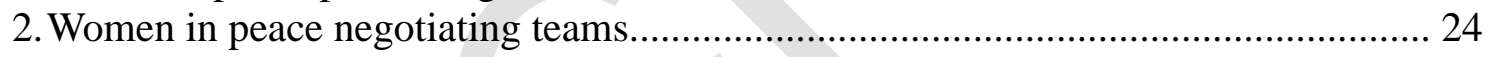

3. Women's participation in the Justice and Security sectors.................................... 27

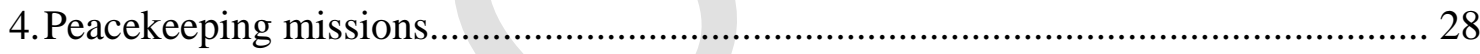

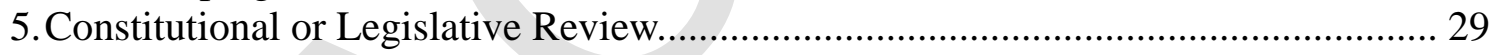

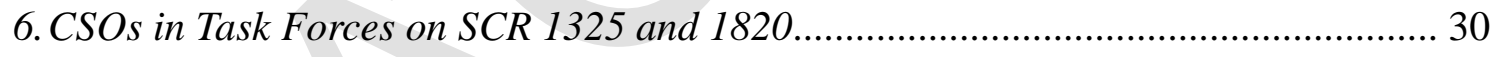

B. PREVENTION and PROTECTION

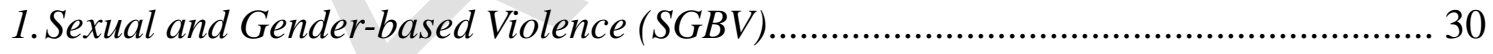

2. Gender responsive laws and policies.................................................................. 34

3. Truth and Reconciliation Commission (TRC) and other transitional justice............. 37

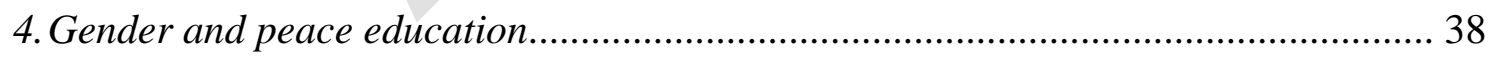

C. PROMOTION OF A GENDER PERSPECTIVE.................................................. 38

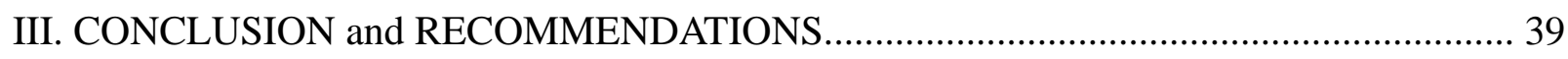

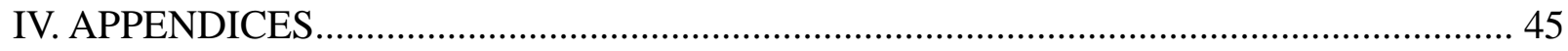




\section{ACRONYMS}

$\begin{array}{ll}\text { AWN } & \text { Afghan Women's Network } \\ \text { ACBAR } & \text { Agency Coordinating Body for Afghan Relief } \\ \text { ANCB } & \text { Afghan National Coordinating Body } \\ \text { ANSF } & \text { Afghan National Security Forces } \\ \text { APRP } & \text { Afghanistan Peace and Reconciliation Program } \\ \text { AIHRC } & \text { Afghanistan Independent Human Rights Commission } \\ \text { ANDS } & \text { Afghanistan National Development Strategy } \\ \text { CEDAW } & \text { Convention on Elimination of All Forms of Discrimination Against } \\ & \quad \text { Women } \\ \text { DOWA } & \text { Department of Women's Affairs } \\ \text { EVAW } & \text { Elimination of Violence Against Women } \\ \text { FETs } & \text { Female Engagement Teams } \\ \text { GoA } & \text { Government of Afghanistan } \\ \text { HPC } & \text { High Peace Council } \\ \text { IDPs } & \text { Internally displaced persons } \\ \text { ISAF } & \text { International Security Assistance Force } \\ \text { NAP } & \text { National action plan } \\ \text { NAPWA } & \text { National Action Plan for the Women of Afghanistan } \\ \text { NATO } & \text { North-Atlantic Treaty Organization } \\ \text { MDGs } & \text { Millennium Development Goals } \\ \text { MOD } & \text { Ministry of Defense } \\ \text { MOFA } & \text { Ministry of Foreign Affairs } \\ \text { MOI } & \text { Ministry of Interior } \\ \text { MOJ } & \text { Ministry of Justice } \\ \text { MoLSAMD } & \text { Ministry of Labor, Social Affairs, Martyrs and the Disabled } \\ \text { MOWA } & \text { Ministry of Women's Affairs } \\ \text { MPH } & \text { Ministry of Public Health } \\ \text { PRTs } & \text { Provincial Reconstruction Teams } \\ \text { SGBV } & \text { Sexual Gender Based Violence } \\ \text { TRC } & \text { Truth and Reconciliation Commission } \\ \text { UNAMA } & \text { United Nations Assistance Mission in Afghanistan } \\ \text { UN SCR } & \text { United Nations Security Council Resolution } \\ & \end{array}$




\section{Women, Peace, and Security Profile}

\section{Introduction}

In Afghanistan, directly as a result of violent conflict, women face displacement, the possibility of becoming internally displaced, the loss of male heads of household, lack of access to work and economic improvement and mobility, and the limited access or total denial of education. Violent conflict affects the space women occupy and the security women have within the family, community, and country. In this state of conflict, women are more prone to being used for human trading, trafficking, rape, and abuse. The effects of conflict on the whole community makes women and girls a focus point on which honor, prestige, and wealth revolve.

Currently in Afghanistan there is no national action plan (NAP) on United Nations Security Council Resolution (UN SCR)1325.

This report examines the United Nations Security Council Resolution (UN SCR) 1325 implementation in Afghanistan using a set of indicators developed originally by AWN and other members of the Global Network of Women Peacebuilders (GNWP). Indicators where fine tuned through consultations with AWN members and used for field based and desk research in Afghanistan. Obtaining valid quantitative information from ministries and the provinces with limited staff and budget proved to be a major challenge in this research. While researchers based in the provinces were given training on the research goals and the methods to go about obtaining data, finding suitable and willing participants to provide information without a monetary incentive proved to be a challenge.

It is still quite difficult to get the specific perspective of women who live in rural or difficult to reach localities in Afghanistan. The voices heard in activist circles, national and international conferences are the voices of mostly urban, educated or semi-educated women. However, over the past ten years, Afghan women activists' concerns have focused on areas that affect in general terms women and girls who come from rural, urban, literate and illiterate backgrounds. Areas that affect all Afghan women include women's participation in governance, justice, security, and peace as well as policies that address prevention and protection of women from violence and sexual-gender based violence (SGBV).

\section{A. Nature of the conflict}




\section{Country Background on Conflict}

After over thirty years of violent conflict, every facet of Afghan socio-political infrastructure, law and governance, community harmony, civilian life, economy and trade have suffered. Depending on who is asked, the conflict that continues may be termed as a continuously shifting internal clash of interests, values, or needs of conflict parties, or as the central crux of a regional and international struggle to fulfill or enhance economic and security needs of neighbors and world powers. It remains to be seen how the parties in conflict will come to an agreement on the terms for peace. To reach this agreement, women and proponents of women's rights in Afghanistan are concerned that the milestones and gains achieved by women and guaranteed by the new government may be bartered away at the negotiation table, taking away hard won rights. Meanwhile, Afghanistan as a state within the cusp of the Middle East-Central Asia-South Asia region continues to be a dangerous place for women ${ }^{1}$, where maternal mortality is among the highest in the world ${ }^{2}$, and women face violence, economic and general discrimination due to gender, and appalling access to health services. ${ }^{3}$ As a conflict hotspot, it is also a dangerous place for all Afghan nationals, foreigners, government, NGOs, Afghan businesses, banks, hotels, civil servants, police, soldiers, and women's rights and human rights activists. Suicide attacks or other bombing can happen at any time.

Government policies inadequately respond to the economic needs of those who previously made a living growing the opium poppy plant, forcing many to go back into poppy production or falling back into poverty. ${ }^{4}$

In urban areas such as Kabul, where it is relatively free from direct violent conflict, except for the occasional attack or suicide bombing, personal carrier convoys marauding through traffic, huge cement blocks protecting homes, offices, businesses, ministries, and embassies, heavily armed personal bodyguards, and police in helmets securing traffic circles and certain roads within the city, are a common sight. The pictures of assassinated political figures mark shop windows and the windows of civilian and armored cars.

\footnotetext{
1 "The world's five most dangerous places for women," poll by TrustLaw Women, Thomson Reuter's Foundation global poll of experts, June 2011.

2 "Maternal Mortality Ratio". International Human Development Indicators. Accessible http://hdrstats.undp.org/en/ indicators/22406.html

3 UNICEF-Afghanistan Statistics. http://www.unicef.org/infobycountry/afghanistan_statistics.html. Accessed $6 / 12 / 2011$.

${ }^{4}$ For more information on some of the problems facing eradication and alternative livelihoods, refer to Walsh, Declan and lan Black. "Eradication or legalisation? How to solve Afghanistan's opium crisis". The Guardian. August $29,2007$. Accessible http://www.guardian.co.uk/world/2007/aug/29/afghanistan.foreignpolicy; "In-depth: Bitter-Sweet Harvest: Afghanistan's New War" IRIN News. August 2004. Accessible http://www.irinnews.org/InDepthMain.aspx? InDepthld=21\&Reportld=63020; AREU Briefing Paper: Mansfield, David and Adam Pain. "Opium Poppy Eradication: How to raise risk when there is nothing to lose?". Afghanistan Research and Evaluation Unit (AREU). August 2006. Accessible http://www.areu.org.af/Uploads/EditionPdfs/625E-Opium\%20Eradication-BP-print.pdf;
} 
Until the removal of the Taliban from power, Afghanistan as a state and as a society was devastated and its very foundations had hit a ground zero, but the country has made a slow incline toward rehabilitation even while a conflict in many areas, especially the south and east, continues. While all of Afghanistan continues to feel the impact of war through social and economic deprivations and physical insecurity, the ongoing conflict has been most deadly in areas bordering Pakistan, where the majority of the fighting and Taliban and other militant activity continues to occur.

Central and northern areas previously seen as secure have fallen into violence. For years the northern provinces were seen as safe areas with good security, despite the problem of land disputes between communities. Taliban control areas immediately outside of Kabul Province, including the provinces of Logar, Maidan Wardak, Ghazni, Musahi in Kabul Province. For the past five years violent conflict related to the insurgency in the south has been on the rise, creating large waves of IDPs into the city of Kabul and other urban and rural areas. ${ }^{5}$

A rise in the intensity of the conflict between Taliban and other insurgent groups and the Afghan government and NATO-led troops was seen beginning in 2005. Each year since then has brought increasing numbers of civilian as well as soldier and police deaths. Taliban, other insurgent groups, criminal cartels, drug rings, warlords, local militias, and former mujahideen commanders (and their families) all serve as elements that continue to destabilize communities and whole provinces or country regions, that refuse to allow the implementation of the rule of law and honest governance to take root in their areas, and perpetuate a violent system in the area that denies rights to both men and women, including the right to life, property, and justice. ${ }^{6}$

At the national level, impunity continues to be the rule rather than the exception, where the government routinely fails to prosecute criminals and human rights violators acting as politicians and local bosses. Ensuring this attitude are attempts at creation of laws that provides amnesty to human rights violators who hold office from government prosecution. In 2007 attempts were made to pass the National Stability and Reconciliation Law, but was passed into official law in 2009. Respect for and protection of the human rights of Afghans and foreign workers is severely lacking in Afghanistan.Abduction and often killing of foreigners and Afghans who are citizens of Western states as well as wealthy Afghan nationals is common enough to warrant fear of its daily possibility. ${ }^{7}$

\footnotetext{
${ }_{5}$ Refer to Internal Displacement Monitoring Centre Afghanistan page for a more in depth look at the situation of IDPs in Afghanistan. Accessible http://www.internal-displacement.org/countries/afghanistan

6 “Just Don't Call it a Militia." Human Rights Watch. September 2011. Accessible http://www.hrw.org/news/2011/09/12/ afghanistan-rein-abusive-militias-and-afghan-local-police.; Jalalzai, Musa Khan. "Play Boy, Forced Marriages, and Prostitution". The Daily Outlook Afghanistan. July 4, 2011. Accessible http://outlookafghanistan.net/topics? post_id=1117.
}

${ }^{7}$ Afghanistan Chapter Summary. Human Rights Watch. January 2011.; Anecdotal information from Kabul residents. 


\section{Conflict Actors}

The current conflict in Afghanistan involves a number of actors: the Afghan government, the Taliban and other anti-government groups such as the Hekmatyar group ${ }^{8}$, as well as the Haqqani network ${ }^{9}$ in Pakistan and the strategic geo-political interests of the state of Pakistan. The situation is one of on-going conflict, with some areas affected more continuously than others. Conflict violence can take the form of aerial bombings, ground operations, and suicide bombings. Afghanistan is a highly militarized country, where a gun culture has traditionally existed in non-urban areas and the use of violence to resolve a dispute is not uncommon. ${ }^{10}$ Supporting the conflict is the prominent drug trade, where Afghanistan ranks as the number one producer of opium to the world, and in the battle for drug profits both communities and the rule of law is weakened. ${ }^{11}$

Taliban activities harm and threaten civilians on the one hand, and the government's lack of resolve to investigate crimes, prosecute perpetrators, and protect civilians from criminals and human rights violators continues to prove that no one in power stands for the benefit of the people. Insecurity, a burgeoning youthful population where 75 percent of Afghans is below 25 years of age, lack of jobs, and violence continue to promote a paradigm of life in that serves to keep the social fabric of the country and support for and effectiveness of the government weak. ${ }^{12}$

\section{B. Impact of Conflict on Women}

\footnotetext{
8 Gulbuddin Hekmatyar is sanctioned by the US Treasury Office of Foreign Asset Control on the list of "Specially Designated Global Terrorists" (http://www.ustreas.gov/offices/enforcement/ofac/programs/terror/terror.pdf )and on the United Nations' Consolidated List, a sanctions list, mandated by UN SCR 1267. http://www.un.org/sc/committees/ 1267/NSQIH8803E.shtml.

9 The Haqqani network, also on the UN sanctions list, operates in Pakistan and over recent years has stepped up attacks on government and international targets within Afghanistan.

10 "Guns out of control: the continuing threat of small arms". IRIN News. May 2004. Accessible http:// www.irinnews.org/InDepthMain.aspx?InDepthld=8\&Reportld=34289; Morris, Kylie. "Afghanistan's gun culture challenge". BBC News. February 22, 2003. Accessible http://news.bbc.co.uk/2/hi/south_asia/ 2788167.stmlivepage.apple.com

11 "Illicit Drugs" CIA World Factbook. Accessible https://www.cia.gov/library/publications/the-world-factbook/fields/ 2086.html; "Afghan opium production halved". BBC News. September 30, 2010. Accessible http://www.bbc.co.uk/ news/world-south-asia-11442411.; "Afghanistan Opium Survey 2010" UNODC. December 2010. Accessible http:// www.unodc.org/documents/crop-monitoring/Afghanistan/Afghanistan_Opium_Survey_2010_web.pdf.; "Global opium production". The Economist. June 24, 2010. Accessible http://www.economist.com/node/16432922.

12 Group discussion with Afghan men and women of varying age, sex, and personal background. Kabul, Afghanistan. April 15, 2011.
} 
For women the situation is even more dangerous not only due to the conflict and the lack of adherence to the rule of law but also due to the impunity of violators, and the cultural shame of speaking out, especially to the police or in court, domestic violence, harassment, assault, rape, and targeted kidnappings and killings. Women tread the streets and large public places of Kabul and other major cities with caution and weariness for both security from a suicide attack and security from verbal or physical harassment. Afghan women, girls, and young boys are also prime victims of abductions and human trafficking within Afghanistan and to countries such as Iran, Pakistan, and Arab states as drug mules, bonded slaves, and prostitutes. ${ }^{\mathbf{1 3}}$

\section{Gender and Conflict}

All Afghans have suffered during the last 30 years of conflict, but women have suffered on a number of levels. During the armed phase of each violent conflict in Afghanistan, women have faced not only the dangerous conditions violent conflict brings to life, limb, and property, they have also withstood negative cultural practices that existed long before any war erupted in the country, rape, physical insecurity due to gender, forced and early marriage, customary practices of bad and badal kardan ${ }^{14}$, denial of the right to education, access to justice and health care, the right to work, the right to be involved in the public and social affairs of their communities, and the right to self-determination. These denials and abuses existed before violent conflict erupted and mutated over the past 30 years, but the war environment has further exacerbated the denials and abuses faced by women and girls all over Afghanistan.

While it is the Taliban who receive a media spotlight and policy focus on past crimes against women, former mujahideen and communist governments are responsible for violence and sexual violence affecting women and girls. Although sexual and gender based violence (SGBV) have not taken the face it has in conflicts such as in Bosnia or in the Democratic Republic of Congo (DRC), its prevalence and effect on women's lives is real and detrimental to the future of most born female in Afghanistan. A recent survey found Afghanistan to be the most dangerous country for women or girls to live in. ${ }^{15}$ Based on a number of core issues, among them lack of access to health care and maternal mortality, economic discrimination, and non-sexual violence (conflict related or domestic, physical, or mental abuse), Afghanistan ranked highest as most dangerous, placing ahead of countries such as the Democratic Republic of Congo (DRC) and Somalia.

\footnotetext{
13 "Trafficking in Persons in Afghanistan". IOM Field Survey Report. June 2008. Accessible http://www.iom.int/jahia/ webdav/shared/shared/mainsite/activities/countries/docs/afghanistan/iom_report_trafficking_afghanistan.pdf

14 baad is a customary practice among certain groups within Afghanistan. It is a conflict resolution method used by a community to resolve a dispute or transgression where the male offender's sister or other female relative is given or taken as the wife of one of the males of the offended party; badal kardan is a common practice among rural and urban Afghans wherein two girls or women are exchanged between two families in order to ensure harmony between the two. This also ensures that the girls are not abused or mistreated since if one is mistreated or abused, the other one will be also in retaliation.

15 The world's five most dangerous countries for women, TrustLaw Women, A Thomson Reuters Foundation global poll. Accessed July 10, 2011
} 
Today, women face all of these issues and while there are positive aspects within the Constitution, certain laws and policies, and improvements in certain areas such as the number of girls attending school, there is still much to be desired. The security situation makes access and movement difficult for women and girls to take part in work and education and it is often a direct reason why families do not send their girls to school. ${ }^{16}$ Girls face attacks for attending school, and women face being incriminated as adulterers for interacting with unrelated men. ${ }^{17}$ Women working in a wide variety of sectors risk violence or harassment, often in the form of "night letters' or telephone and text messages. These threats prevent women from going to work to ensure the security and safety of their families and themselves.

Cultural taboos and values objectify women in much of Afghanistan as inanimate objects in an overwhelmingly patriarchal, clan based, male owned and male dominated society, where they should not speak their minds or think for themselves, where they are expected to serve the family and later the husband's family, without a protest. Those who do protest against abuse they face in their homes often have a gathering of elders decide on their complaints, sometimes reach women's shelters, which are few and far in between to begin with, or they turn to suicide or selfimmolation with the intent of suicide. Self-immolation by women and girls in Afghanistan is a rising practice in response to the abuse and violence many face but find escape or obtaining help an impossible reality. ${ }^{18}$

\section{Abuse, Violence, and Recourse}

In the public and private sphere women do not fare much better than they have in the past. While no laws decree Afghan women remain invisible and silent as they did during the Taliban rule, women still in large part live in Afghanistan knowing their security and their own bodies are at risk of violence. At the root, the same problems remain for Afghan women as they have for decades and are reinforced and projected by cultural sensitivities and taboos, often under the false guise of being a part of religious dogma.

Physical and psychological abuse, sexual and gender based violence (SGBV), domestic and physical violence, cultural and social restrictions on women's space, voice, and movement dot

\footnotetext{
16 See for example the report on girls education by Oxfam International, "High Stakes: Girls' Education in Afghanistan". February 24, 2011. Accessible http://www.oxfam.org/en/policy/high-stakes-girls-education-afghanistan.; Kelly, Anne. "Afghan girls' education backsliding as donors shift focus to withdrawal". BBC News. February 24, 2011. Accessible http://www.guardian.co.uk/global-development/2011/feb/24/afghanistan-girls-education-report

17 "Afghanistan Chapter Summary". Human Rights Watch. January 2011.; Report from AWN partner working in south zone.

18 "Self-immolation of women in Afghanistan". medica mondiale. 2006-2007 Report. Accessible http:// www.medicamondiale.org/fileadmin/content/07_Infothek/Afghanistan/Afghanistan_Dying_to_be_heard_ self_immolation_medica_mondiale_2007.pdf; Hauslohner, Abigal "Afghanistan: When Women Set Themselves on Fire". TIME. July 7, 2010. Accessible http://www.time.com/time/world/article/0,8599,2002340,00.html
} 
the landscape of a gender discussion in Afghanistan. ${ }^{19}$ Social or family restrictions limit women on their right to work, to choose their spouses, or to continue their education. Women who do work risk the threat of violence against themselves or their families, ridicule by society and extended family, and gossip centered on the morality of such women.

Women and girls addicted to drugs has become common in Afghanistan. A majority of drug addicted women are married with children and often face a difficult life, take part in labor intensive work, or have severe health problems. Opium and other drug use is seen as a way to cope with these realities but drug addiction also happens to women and girls as a result of many other factors. Some are fed opium smoke as children by their mothers to quiet them, while others become addicted in adolescence or adulthood under the guidance of their husbands, who are already addicts. A study by the AIHRC revealed that drug use in Afghanistan, especially in rural areas, is a result of usage in the family environment. Often the husband or father is the original user and either pushes the habit onto family members, especially his wife, or family members become users as a result of breathing in the smoke frequently. ${ }^{20}$

There are a limited number of places to which women who face violence or are in need of protection can turn. Women who seek help from police meet with verbal, physical, or emotional abuse from officers and they often run the risk of being arrested especially if the woman has left her husband's or father's home due to violence or another reason, such as forced marriage, or if the complaint is sexual assault or rape. ${ }^{21}$ Women who make up the female segment of the prison population are often there because they have been accused of immoral behavior rather than violent crimes or theft. While zina (adultery) is a crime under Afghan law, being the victim of rape, sexual abuse, leaving the place of domestic violence, or leaving home to marry a man of her choice are not crimes. ${ }^{22}$

The apathy of police toward the complaints women and girls lodge as well as cultural attitudes further victimize these women is indicative of a major flaw in the prevention of and protection from violence against women and girls. Placing victims into prison where they often face more abuse at the hands of authorities or forcing them back to their homes without a just resolution to their problems is often the response of law and order. Furthermore, the belief that individuals who act against cultural morality norms must be punished is a strong undercurrent in the way police and other authorities responded to cases involving women, and especially when it concerns women's actions and morality. In Afghanistan, women are punished for being raped or being victims of violence, and speaking out or leaving the home to seek protection or end further

\footnotetext{
19 Separate interviews with rights activists working in Herat, Kabul, Kandahar, Panjshir, Khost, Bamiyan, and Takhar.

20 "Effective Factors Associated with Drug Addiction and the Consequence of Addiction among Afghan Women", Afghanistan Independent Human Rights Commission (AIHRC), Research and Planning Section, February 2008. www.aihrc.org.af/2010_eng/Eng_pages/Reports/Thematic/Rep_Afghan_women_Drug_Abuse.pdf

21 Interview with Herati women's rights advocate, Kabul, Afghanistan. May 26, 2011

22 Interview with Afghan human rights activist and lawyer. Kabul, Afghanistan. August 27, 2011
} 
abuse. Rapists and other perpetrators are either not punished at all, given a lenient sentence, or given the choice to marry their victim in the case of rape. ${ }^{23}$

Violent attacks on and threats against women politicians, media personalities, rights activists, NGO or government workers and acid and poison attacks on school girls is common news throughout the country in the past ten years. Heightened insecurity and an intensely conservative culture adds to the lack of effort on improving the public and private space for women and girls. Such areas make it difficult for girls to attend school and for women to work outside the home. These factors also keep Afghan and foreign NGOs from working in rural and difficult to access areas of the country where women's rights are most in need of improving. Many international donors fund projects that focus on urban or semi-urban centers, leaving out areas most in need of help. Focus on the 34 provinces as a whole or enter into areas previously untouched by foreign aid, such as the province of Daikundi, are recent efforts in improving funding and program strategy by international actors. Inevitably, this also means that women in areas unfrequented by government or by Afghan and foreign NGOs lack access to justice, health care, and education, among other needs and their voices are the least heard by Afghan activists and by international actors.

\section{Women in Public Space}

Despite the issues and challenges facing women in Afghanistan, in relatively peaceful, mostly urban areas women are part of the public environment. Women take part in civil society, police, and government sectors, attend school, and teach as university professors, albeit in small numbers. While election quotas reserve political seats for Afghan women to ensure up to 28 percent of women in the Parliament, these quotas only improve the situation of women to the extent of breaking the dominance of men's presence in the legislative branch. While on the surface it is shown that women are members of the Parliament, the impact of real participation of women who hold seats in either assembly house is difficult to measure qualitatively. Moreover, women's presence in the political arena is limited by issues women lawmakers can touch and the intimidation by the dominant environment to toe the line or face the consequences. These issues can include negative cultural practices, policies and practices that are shaped by religion, or speaking out against the treatment of women and girls in the society.

There are many women MPs who have links to political parties with warlord links, and there are also women who stand as independents and advocate for women's rights. What is falsely understood is that election of women to Parliament or appointment to a post will automatically mean support for women's rights. Instead, not all women lawmakers advocate on behalf of

23 "The Afghan women jailed for being victims of rape". The Independent. August 18, 2008. Accessible http:// www.independent.co.uk/news/world/asia/the-afghan-women-jailed-for-being-victims-of-rape-900658.html; Najibullah, Farangis. "In Afghanistan, rape victims begin to break the silence". Radio Free Europe. September 1, 2008. Accessible http://www.rferl.org/content/Afghanistan_Rape_Victims_Break_The_Silence/1195472.html 
women and employ their own political agendas through the quota system. Some women lawmakers have attempted to introduce policies within the Parliament that give them space to also lend their voices to discussions on the floor of the Upper and Lower House. However, these attempts have been thwarted and ignored by men MPs, who mostly tend to not take their women counterparts seriously. ${ }^{24}$ Furthermore, those who reach the level of ministries and Parliament face the threat of violence by Taliban or other groups. Women lawmakers who wish to make a change through law and policy shifts are also hard pressed to challenge the inferior status women hold in Afghan society.

\section{Activism on Women's Rights}

The Afghan Women's Network has been involved in bringing awareness in the eight regions of the country on UN SCR 1325 to Afghan men and women and has been working with Afghan policymakers through advocacy on key aspects of the Resolution. These aspects include participation of women at the decision-making level and awareness on the legal rights guaranteed by the Constitution and Afghan law. Through project based funding from international organizations and UN organs AWN along with other Afghan civil society groups and NGOs have supported advocacy training for women on the High Peace Council, and given awareness on the legal and civil rights of women as well as the relevance of UN SCR 1325 implementation to both men and women in provincial districts in the eight zones of Afghanistan.

In response to physical violence and SGBV, activists have traveled to places such as the province of Kundoz, where a young girl was raped by a group of men without any repercussions, and have lobbied with the governor and president for a focus on this issue. ${ }^{25}$ Furthermore, in 2011, representatives of over twenty women's organizations visited the 34 provinces to speak face to face with provincial governors on the issues women face. Provincial governors signed onto a memorandum that they would include women at provincial level discussions and decisionmaking. This memorandum is not legally enforceable and therefore, its implementation is in the hands of the governors who have signed it and does not have a monitoring body.

The situation of women has certainly made great strides since 2001, and women and girls have found access, albeit limited, to both education and work. Quotas and strategies such as NAPWA have increased the numbers of women in governance and the justice and security sectors. In cities, women are very much a visible part of the daily life, and on the television screen as actors, news anchors, and talk show hosts. Considering these superficialities, life is normal and to a

\footnotetext{
24 Gopal, Anand. "Women lawmakers battle warlords”, IPS ipsnews.net. http://ipsnews.net/news.asp?idnews=46028. Accessed June 15, 2011.

25 Royee, Zafar Shah. "Concerns about a radicalizing influence on girls in Northeastern Afghanistan". Daily 8 am (Hasht-e Sobh). Translated by Neelab Hakimi. May 30, 2011. Accessible http://www.boell-afghanistan.org/web/114Concerns_about_Radicalizing_Influence_on_Girls_in_Northeastern_Afghanistan.html; "Just Don't Call it a Militia." Human Rights Watch. September 2011. Accessible http://www.hrw.org/news/2011/09/12/afghanistan-rein-abusivemilitias-and-afghan-local-police
} 
degree free for women. However, underneath these strides, Afghan women continue to face discrimination and violence at the hands of their own society. Both the history and current environment of war violence play a role in the dehumanization and violence towards women.

Data collected thus far indicates that despite the great strides made, women in Afghanistan have many more to take to live a secure and violence-free life. It is no longer enough to merely set quotas and speak about women's rights without fully engaging the removal of negative practices and policies safeguarded by culture or government entities. Instead, the Afghan government, civil society, human rights and women's rights activists, and the international community in Afghanistan must advocate through positive policy creation and Afghan context-centric strategies to meet the challenges and obstacles facing the improvement and development of Afghan women and girls.

\section{Relevant Policies and Practices}

Afghanistan is party to a number of United Nations conventions and resolutions that directly address the protection of women's rights. These include the Convention on the Elimination of All Forms of Discrimination Against Women (CEDAW) ${ }^{26}$, and United Nations Security Council Resolution (UNSCR) 1325 on Women, Peace, and Security and the subsequent related resolutions of 1820,1889 , and $1960 .{ }^{27}$ The national effort toward the inclusion and mainstreaming of gender into the political and social sectors are a number of government documents that support space and equality for women's participation and inclusion in public life and protection against violence against women of Afghanistan. These include the Afghanistan Constitution, the National Action Plan for Women of Afghanistan (NAPWA), and components of the Millennium Development Goals (MDGs) based Afghan National Development Strategy (ANDS).

\section{Afghanistan Constitution}

The Afghan Constitution, approved through the Constitutional Loya Jirga in 2004, is in line with international human rights norms and values, including freedom from torture, and right to life and liberty, due process, expression and speech, and peaceful assembly. Women stand equal under the law according to the constitution. Greater due is given to Islamic law in the constitution, however, whether it goes against human rights principles or not.

The Constitution of Afghanistan clearly defines the equality of men and women in both rights and duties under the State, prohibiting discrimination and privilege based on gender and

\footnotetext{
26 "Convention of Elimination of All Forms of Discrimination Against Women (CEDAW)". United Nations. 1979. Accessible http://www.un.org/womenwatch/daw/cedaw/cedaw.htm

27 For an overall briefing on commitments to women by the government, refer to Appendix 4 .
} 
ethnicity. Article 22 states this explicitly, ideally making principles of gender equality and nondiscrimination a key component in policies set by the government and in the laws passed by the legislative house. Article 44 seeks to promote women's education, while Article 53 promises State financial support to women-headed households (women without 'caretakers'). Article 54 commits the State to supporting the well being of children and mothers, as well as eliminating harmful traditions contrary to Islamic principles. ${ }^{28}$ Articles 83 and 84 collectively are concerned with the Afghan National Parliament, reserving two seats from every province in the Lower House (Wolesi Jirga or House of the People), and half of one-third in the Upper House (Meshrano Jirga or House of Elders) for women. ${ }^{29}$

\section{Afghan National Development Strategy (ANDS)}

The Afghan National Development Strategy (2008-2013) is in support of the Afghanistan Compact benchmarks and the Millennium Development Goals (MDGs). ${ }^{30}$ Gender equity is included as part of the ANDS major cross-cutting issues. Overall components of the ANDS implementation include equitable development and poverty reduction, security, gender equality, macroeconomic stability, private sector development, and employment. Gender policy in the ANDS is both cross-cutting sectorally, where implementation of gender mainstreaming themes is mandatory upon all government ministries and agencies, as well as the key to the whole process of development in Afghanistan. ${ }^{31}$

While all the components of the ANDS impact women in one way or another, the gender equality component is key to addressing the gender imbalance in many areas of social, political, and cultural life of Afghanistan. Furthermore, it ensures that budget creation takes gender into account. The ANDS shares with NAPWA the goal of elimination of discrimination against women, approaching its work through a ten-point development strategy.

\section{National Action Plan for Women of Afghanistan (NAPWA)}

After nearly four years of consultations and planning by the Ministry of Women's Affairs and the NGO Coordination Group, made up of the Afghan Women's Network (AWN), the Agency Coordinating Body for Afghan Relief (ACBAR), and the Afghan NGO Coordinating Body

\footnotetext{
28 For a recent account of negative traditions, refer to "Harmful Traditional Practices and Implementation of the Law on Elimination of Violence against Women in Afghanistan". UNAMA and OHCHR. December 9, 2010. Accessible http://unama.unmissions.org/Portals/UNAMA/Publication/HTP\%20REPORT ENG.pdf

29 Constitution of the Islamic Republic of Afghanistan. 2004. Accessible http://www.afghanembassy.com.pl/cms/ uploads/images/Constitution/The\%20Constitution.pdf

30 Afghanistan Compact. 2006. Accessible http://www.nato.int/isaf/docu/epub/pdf/afghanistan_compact.pdf

${ }^{31}$ Afghanistan National Development Strategy (ANDS). Oversight Committee and the ANDS Secretariat for the Government of Afghanistan, 2008-2013. http://www.undp.org.af/publications/KeyDocuments/ANDS_Full_Eng.pdf
} 
(ANCB), on May 19, 2008, the National Action Plan for Women of Afghanistan (NAPWA) was accepted by the Karzai Cabinet. ${ }^{32}$ The NAPWA is a ten year plan to meet development goals with a gender mainstreamed vision and as a framework to reach gender commitments made in the Constitution, the Afghanistan Compact, and the Millennium Development Goals (MDGs), along with other national documents. However, no major efforts on a NAP on UN SCR 1325 has taken place in Afghanistan until recently. Currently, civil society groups have come together with key government ministries and committed international donors to begin the planning process of an Afghanistan NAP. ${ }^{33}$ Where this process will lead remains to be seen in the coming 2011-2012 year cycle.

The National Action Plan for Women of Afghanistan (NAPWA) is an effort by the Afghan government to support the advancement of women through gender equality in all social and political realms of the public sector. Specifically, this strategy framework is the responsibility of the government of Afghanistan to implement in all ministries and provincial ministries. Its two pronged approach is gender equality and empowerment of women. The plan has come about based on the guidelines and commitments of the Afghanistan Compact and Afghan National Development Strategy (ANDS) and its implementation fulfills benchmarks set within the Compact and the ANDS. For the government of Afghanistan this as major component of achieving gender equality and mainstreaming through a systemic and sustainable method at a variety of government ministries, agencies, and provincial government bodies. The overall goal of NAPWA is to create, within institutions, both a concern for gender issues and the inclusion of women when creating budgets, policies, services, recruitment, promotion, and opportunities. CEDAW is included in the NAPWA as a key obligation to follow through by the government of Afghanistan in implementing gender equality and women's empowerment.

While gender tolerant and progressive documents exist, the Afghan government has been slow to produce major improvements in the inclusion and protection of women, and it has not provided a report or analysis on UN SCR 1325. The government is however in the process of submitting a report on CEDAW, the first of its kind from Afghanistan since the ratification of this convention in 2003. Despite the presence of a constitution friendly toward women, there are laws that ultimately sacrifice the rights of women and girls in Afghanistan. Passage of such laws as the Shia Personal Law and the National Reconciliation, General Amnesty and Stability Law, or Amnesty Law harm women's gains and threaten constitutional rights. ${ }^{34}$ Negotiation with Taliban and other insurgent elements who would deny Afghan women any recognizable rights raise fear among women and human rights groups. Other social concepts such as honor and shame, the practices of bad and badal, and cultural codes all affect women in severely negative ways.

\footnotetext{
32 National Action Plan for Women of Afghanistan (NAPWA). Ministry of Women's Affairs, Government of Afghanistan, 2008. Kabul, Afghanistan. pp. vii

33 Meeting with key UN SCR 1325 stakeholders, Kabul, Afghanistan. April 17, 2011

34 See a joint paper by AIHRC and the Centre for Transitional Justice, "Discussion paper on legality of amnesties". February 21, 2010. Accessible http://www.aihrc.org.af/2010_eng/Eng_pages/Reports/Thematic/ Amnesties_paper_23_Feb_2010.pdf
} 


\section{Customary Codes and Practices}

In Afghanistan, it is customary law that has replaced law and order, especially in non-urban areas. Without the arm of law and order of government, in most areas of Afghanistan, families, communities, and villages have maintained order through entrenched traditions influenced or directly sourced from old tribal codes and unified under a false understanding of religious concepts.

\section{Pashtunwali}

Pashtunwali is one set of tribal traditions and values, or code of ethics, which most people erroneously believe to have religious legitimacy, practiced by Pashtun communities. It is a major influence on the values and customary law of other ethnic groups within Afghan society, as well. ${ }^{35}$ While women are supposed to be respected under this code, their honor and protection is bound by whether they follow the traditions of the community, appear honorable, and do not trespass gender boundaries. With the breakdown of Afghan institutions such as the police and the justice system, rising conservatism due to instability, ${ }^{36}$ and mistrust of whichever faction happens to be in power, many Afghans rely on community based conflict resolution methods found within customary law and the informal court system where community, tribal, or district elders act as arbitrators and judges on a crime or a complaint.

\section{Honor and Shame}

The concept of honor (namus) and shame is deeply entrenched in Afghan society and like aspects of Pashtunwali, this also transcends ethnic groups in Afghanistan. Maintaining honor is often the preserve of male members of a family or a community and its protection is often channeled and upheld through the actions and appearance of female members of a family or community. In effect, women are the bearers of men's and their community's honor, and trespassing the purity of this honor can be a serious issue for women and girls. Trespassing can occur in a number of ways, from simply being seen lingering near a window or doorway one too many times, to coming home late, going out of the house without permission, to being seen talking to a man or boy who is not a direct relative of the woman or girl. Male and sometimes female members of families control the decisions, education, marriage, choice of spouse, outside work and the place of work, style of dress, interaction with individuals outside the immediate household, and the freedom of movement of a woman or girl, in order to maintain honor. Those who trespass the

\footnotetext{
35 Pashtunwali and Afghanyat are both two similar codes of conduct which essentially dictate the values and accepted actions within the Afghan society. Both refer to the sense of Afghan-ness and under both, women are the docile figure, without agency, to the dominant role given to men. Women who are assertive or speak their minds are seen as obnoxious and angry, 'free' which infers moral looseness and not to be emulated, or 'mardana' (manly) for taking on male attributes. For more information on Pashtunwali and women, please see an informative essay by Palwasha L. Kakar, Accessible http://www.law.harvard.edu/programs/ilsp/research/kakar.pdf.

36 Ward, Jeanne and Mendy Marsh. "Sexual Violence Against Women and Girls in War and its Aftermath, Realities, Responses, and Required Resources." UNFPA, 2006. Accessible http://www.unfpa.org/emergencies/symposium06/ docs/finalbrusselsbriefingpaper.pdf
} 
limits set by their families and communities face abuse, physical violence, dismemberment, or death.

While the concept of honor and shame is not paramount in every family, as a whole it tends to be a shared value among Afghans. The mindset of honor and shame makes it difficult for women and girls to be functioning members of the public space. Through anecdotal evidence, it is apparent that this mindset can make a husband doubt his wife ${ }^{37}$, whom he thinks is overly attractive, should she work outside the home, a brother to slap his sister for coming home after working late in the office ${ }^{38}$, or a newly married high school age bride to be forbidden to continue attending school due to the in-laws' assertion that they do not want their daughter-in-law outside the home so often. ${ }^{39}$ In such cases, most women including these highlighted, accept their situations and identify with the cultural mindset that victimizes them.

Women and girls who face physical, emotional, or sexual violence have very little recourse. Most victims of such violence remain quite for fear of violent repercussions or shame on their families. Some react or rebel by attempting suicide, including self-immolation, which is increasingly an often employed method of suicide, ${ }^{40}$ or they 'runaway' from home by going to a women's shelter, a provincial branch of the Ministry of Women's Affairs, or sometimes police. ${ }^{41}$ Those who go to these places face not only shaming their families, but also the possibility of violence if they are returned to their families without resolution of the original problem. They also face abuse and rape at the hands of police who should be protecting them. ${ }^{42}$

\section{Barter and Exchange - Badal and Bad}

Badal, or 'exchanging' (of girls or women), and bad, which in this context means 'in return'. Badal often takes place when a girl or woman from two families are exchanged in place of one another. This ensures protection of both women and also lowers the possibility of retaliation when one woman is mistreated. Badal seems to be practiced throughout the country, and is not specific to any particular ethnic group. In practice bad is used to give restitution for honor crimes such as murder, rape, and unpaid debts, among others, and while found in all parts of the country,

\footnotetext{
37 Conversation with male graduate of Kabul University, Kabul. July 2011.

38 Conversation with female graduate of Kabul University, Kabul. May 2011.

39 Conversation with high-school age bride, Kabul. August 2011.

40 "Self-immolation of women in Afghanistan". medica mondiale. 2006-2007 Report. Accessible http:// www.medicamondiale.org/fileadmin/content/07_Infothek/Afghanistan/Afghanistan_Dying_to_be_heard_ self_immolation_medica_mondiale_2007.pdf

41 Under Afghan law, 'running away' is not a punishable crime. However, due to the power culture has in society, those who leave home for reasons that are also not crimes under the law are treated like criminals by police and the justice system.

42 "Just Don't Call it a Militia." Human Rights Watch. September 2011. Accessible http://www.hrw.org/news/ 2011/09/12/afghanistan-rein-abusive-militias-and-afghan-local-police
} 
it is practiced more among Pashtun groups. ${ }^{43}$ Motivation for bad may differ depending on province, where according to a report on the practice, some areas use bad in response to murder or crimes against their honor, while in other areas it is used for these cases as well as for theft and other criminal wrongdoing. ${ }^{44}$ Most often the alleged perpetrator is the father, brother, or uncle of the girl or woman that is given as restitution. The girl or woman is usually given to be married with a male member of the offended family and often ends up living the life of a servant in the household. This practice

\section{Informal Courts}

Mistrust of the central government, lack of adequate access to a formal court system, corrupt police, and sometimes the shame of having to bring a private problem to a court within the public space have created a general unwillingness or inability to bring criminal and civil cases to the formal court system. Informal courts practice justice in a mix of customary law, patriarchal notions of gender justice and the rightful lot of women, honor, and an often erroneous understanding of what Islam posits on justice and women's rights. Most especially problematic is the near absolute lack of recognition of women's rights guaranteed by Islam and those protected by Afghan laws and international conventions. In 2010, attempts were made by the Afghan government to give legitimacy to informal courts. However, members within Parliament, civil society, human rights, women's rights activists lobbied to defeat the bill proposing the legitimacy of these courts. Despite this lack of legitimacy in the eyes of activists and the government, informal courts prevail in all parts of Afghanistan, especially for non-criminal offenses. The method and tools used to consider a case are non-technical, unprofessional, and void of linkage to Afghan law or Islamic law. In civil or criminal disputes, often a woman or girl ends up victimized since one of the ways of resolving a dispute is to exchange a girl or a woman between the offending and offended parties. When women have a complaint or are victimized in some way, they cannot approach these informal courts for a number of reasons, including the shame of having to approach an elder council to resolve a private issue, the lack of serious attention given to their complaint, and the tendency to view the problems of women with a subjective patriarchal lens. ${ }^{45}$

\section{Data presentation and analysis}

Data on key indicators of UN SCR 1325 was collected in the eight zones of Afghanistan spanning the 34 provinces, including provinces with weak security. Survey questionnaires and interviews were used to gather data from informants in provincial areas, about an average of

\footnotetext{
43 Based on notes from staff working in areas of eight zones. Staff reported that while it is hard to gather concise information regarding cases, based on conversations they held with police and members of community shuras, they learned that these are major motivating factors if bad is practiced in an area.

44 "Bad Painful Sedative". Women and Children Legal Research Foundation (WCLRF). Part Two, Chapter 1. Report
Accessible http://www.wclrf.org/English/eng_pages/Researches/Badpainful/badpainful.htm
}

45 Similarly, there is a deep shame in approaching a court to resolve an issue. 
thirty questionnaires filled in each of the eight zones. Those surveyed included teachers, police, staff of the provincial arm of MOWA, Department of Women's Affairs (DOWA), human rights workers, members of councils, and staff of women's shelters. Similar to past AWN experience, gathering factual data that directly relates to research questions from the central government ministries or from the provinces without monetary incentives for the survey participant proved to be very challenging.

\section{A. Participation}

Under Taliban rule, women only worked in health professions, such as doctors and nurses and could not be found in any other trade or profession. Kabul went from having female drivers of metro buses in the 1980s to women finding it difficult to find a seat in a bus and even dangerous to ride in a taxi without a male chaperone. Efforts by the Afghan government and key ministries to be open to women have been highlighted through a variety of sources, including the original 2004 work plan set by donor nations and Afghan government stakeholders during the Berlin Conference. Since then, women have increasingly become part of the work force within many government ministries as well as the civil service. Professional women who have returned from neighboring countries are also a part of the general participation of women in public life. Women's political participation is highly visible within the urban landscape of Afghan society. During election season, one can see hundreds of election posters and billboards with the faces of women running for office. The participation of women in the areas of civil service, teaching, and other non-governmental jobs has increased drastically since 2001. Despite these positive steps, more must be done to include the voices and experiences of women from across the provinces into the public sector.

\section{Governance}

Women's participation in key positions of decision-making at the government level is minimal and is not spread out across all areas of governance. For many women to simply run for political office is a sign of having overcome a major hurdle within their families and communities. Often even women who sit in government ministries and the Parliament do so at the permission of their male relatives. Senior positions in this report are identified as those in the upper most echelon of a ministry or other area of government structure, such as minister, deputy minister, a member of Parliament, or a member of the Council of Ministers (cabinet).

Statistical data available on total women government employees shows that out of 328,977 government, 66,672 or 20 percent are women employees. ${ }^{46}$ In some areas such as the Ministry of Women's Affairs, almost all key senior positions are held by women, and the Ministry of Labor, Social Affairs, Martyrs, and the Disabled (MoLSAMD), where both the minister and deputy

\footnotetext{
46 Data compiled from Afghanistan Statistical Yearbook 2009-2010. Central Statistics Organization. CSO Printing Press, September 2010. Kabul, Afghanistan. p 12.
} 
minister are women. In the provinces, women make up a very tiny fraction of government positions overall, but vary according to region (see Figure 1). Employment of women in the governance sector is nearly invisible in the southern and eastern areas while it is the highest in Kabul, most likely due to higher employment of women in the central governance structures versus provincial governance structures. Women government employees are among the highest in the north and northeast regions, beside urban centers such as Herat and Kabul. There may be a number of reasons for this, including regional culture sensitivities to women working and the prevalence of security in the north and northeast versus areas such as Helmand, Zabul, Uruzgan, Paktia, Kunar, Nooristan, and Khost.

Figure 1:

Government Employment of Women and Men in the Provinces 2009-201047

\begin{tabular}{|c|c|c|c|c|c|c|c|c|c|}
\hline Province & Wome & & Men & & Province & Women & & Men & \\
\hline & Total & $\%$ & Total & $\%$ & & Total & $\%$ & Total & $\%$ \\
\hline Kabul & 29142 & 30.8 & 65464 & 69.2 & Kundoz & 1609 & 17.2 & 7745 & 82.7 \\
\hline Kapisa & 447 & 8.1 & 5062 & 91.9 & Samangan & 592 & 14.7 & 3417 & 85.2 \\
\hline Parwan & 1011 & 9.9 & 9122 & 90.1 & Balkh & 6694 & 31.8 & 14329 & 68.1 \\
\hline Wardak & 554 & 11.0 & 4481 & 89 & Sar-e Pol & 901 & 19.0 & 3619 & 80.0 \\
\hline Logar & 398 & 9.5 & 3763 & 90.5 & Ghor & 161 & 3.3 & 4715 & 96.6 \\
\hline Nangarhar & 1285 & 7.1 & 16569 & 92.9 & Daikundi & 512 & 20.4 & 1988 & 79.5 \\
\hline Laghman & 258 & 4.6 & 5269 & 95.4 & Uruzgan & 53 & 2.6 & 1919 & 97.3 \\
\hline Panjshir & 263 & 11.3 & 2064 & 88.7 & Zabul & 80 & 7.0 & 1055 & 92.9 \\
\hline Baghlan & 2015 & 15.3 & 11071 & 84.7 & Kandahar & 585 & 7.1 & 7597 & 92.8 \\
\hline Bamyan & 694 & 14.0 & 4250 & 86.0 & Jowzjan & 2481 & 23.7 & 7984 & 76.2 \\
\hline Ghazni & 1019 & 13.0 & 6811 & 87.0 & Faryab & 1856 & 20.3 & 7283 & 79.6 \\
\hline Paktika & 64 & 1.2 & 4899 & 98.8 & Helmand & 421 & 10.4 & 3633 & 89.5 \\
\hline Paktia & 666 & 13.3 & 4310 & 86.7 & Badghis & 313 & 10.0 & 2808 & 89.9 \\
\hline Khost & 134 & 2.3 & 5468 & 97.7 & Herat & 5670 & 30.5 & 12896 & 69.4 \\
\hline Kunar & 153 & 2.7 & 5392 & 97.3 & Farah & 671 & 15.5 & 3646 & 84.4 \\
\hline Nooristan & 145 & 5.9 & 2274 & 94.1 & Nimroz & 556 & 28.9 & 1366 & 71.0 \\
\hline Badakhshan & 3152 & 21.1 & 11751 & 78.9 & & & & & \\
\hline Takhar & 2147 & 20.5 & 8285 & 79.4 & Total & 66,702 & 25.4 & 262,305 & 74.5 \\
\hline
\end{tabular}

\footnotetext{
47 Data compiled from Afghanistan Statistical Yearbook 2009-2010. Central Statistics Organization. CSO Printing
} Press, September 2010. Kabul, Afghanistan. 
Setting quotas and requiring women's participation as a development deliverable are among the many ways to improve the participation of women within decision-making and policy-making circles. However, quotas and development goals do not protect women from the immediate environment of insecurity due to the ongoing conflict, the threat of violence against them or their families, or the patriarchal system that forces women to toe the status quo or face the consequences.

Within Parliament, about 68 out of 249 seats are reserved for women in the Wolesi Jirga. In the Meshrano Jirga, there are 102 seats, one-third of which are chosen by the president, one-third from provincial councils, and one-third from district councils. According to the Constitution, 50 percent of the one-third appointed by the president must be women. This means that at least 17 percent must be women in the Meshrano Jirga. Since January 2011, President Karzai appointed 34 members to the Meshrano, with 17 woman appointees. In total, representation of women in the Wolesi Jirga is about equal to that in the Meshrano Jirga, which now has 28 women or about 27 percent woman members. While women are chosen by President Karzai to sit in the Meshrano Jirga, the remaining 69 seats of the Upper House are made up of men chosen by the provincial councils which tends to have low representation of women, but must have one quarter of seats available to women. ${ }^{48}$ Since results of the Parliamentary elections in late 2010 , there were 9 seats that are contested, one seat formerly belonging to a woman from Herat who is currently protesting her removal by going on a hunger strike near the Parliament building in a tent. ${ }^{49}$

\section{Figure 2:}

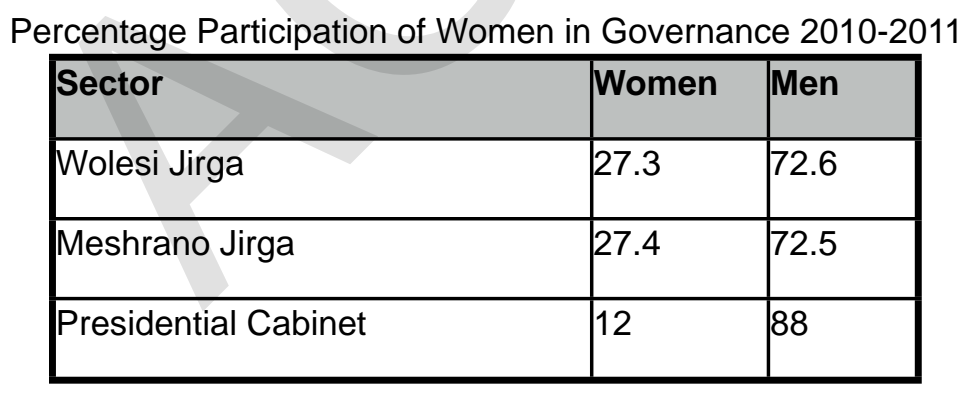

Source: Afghanistan Parliament, 2011.

Women lawmakers are careful with controversial issues that can label them culturally or religiously subversive or extreme, especially in the face of warlords, other government officials, and religious sensitivities. Male members of the National Parliament tend to hold conservative or

\footnotetext{
48 Election Law. Translated by UNAMA and IFES. Accessible at http://www.iec.org.af/pdf/legalframework/law/ electorallaw_eng.pdf

49 Farshad, Lataria. "A female MP, Simin Barakzai who was unseated by the IEC". Pajhwok News. October 4, 2011. Accessible http://www.pajhwok.com/en/photo/158169
} 
downright misogynistic views and current women members explain that there is discrimination on every woman MP who tries to take an active part in floor proceedings. ${ }^{50}$

Former member of Parliament and now a favorite of the anti-war movement in the West, Malalai Joya faced threats against her life and was eventually ousted from her position after voicing her views one too many times on former mujahideen many consider to be responsible for deaths of many Afghans. She eventually fled Afghanistan after receiving countless threats against her and her family's life. Women who have stood up strong through the government system against criminal impunity have faced severe censure and threats against their own safety or that of their families.

Figure 3:

Women Members of Parliament Seats in the Wolesi Jirga

\begin{tabular}{|c|c|c|c|c|c|c|c|}
\hline Province & Population & Total Seats & $\begin{array}{l}\text { Seats Held } \\
\text { by Women }\end{array}$ & Province & Population & Total Seats & $\begin{array}{l}\text { Seats Held } \\
\text { by Women }\end{array}$ \\
\hline Kabul & 3013200 & 33 & 9 & Sar-e-Pul & 463700 & 5 & 1 \\
\hline Kapisa & 367400 & 4 & 1 & Faryab & 824500 & 9 & 3 \\
\hline Parwan & 550200 & 6 & 2 & Badghis & 412400 & 4 & 1 \\
\hline Wardak & 496700 & 5 & 2 & Herat & 1515400 & 17 & 5 \\
\hline Logar & 326100 & 4 & 1 & Farah & 420600 & 5 & 1 \\
\hline Ghazni & 1020400 & 11 & 3 & Nimroz & 135900 & 2 & 1 \\
\hline Paktika & 362100 & 4 & 1 & Helmand & 767300 & 8 & 2 \\
\hline Paktia & 458500 & 5 & 1 & Kandahar & 971400 & 11 & 3 \\
\hline Khost & 478100 & 5 & 1 & Zabul & 252700 & 3 & 1 \\
\hline Nangarhar & 1237800 & 14 & 4 & Uruzgan & 291500 & 3 & 1 \\
\hline Kunarha & 374700 & 4 & 1 & Ghor & 574800 & 6 & 2 \\
\hline Laghman & 371000 & 4 & 1 & Bamyan & 371900 & 4 & 1 \\
\hline Nooristan & 123300 & 2 & 1 & Panjshir & 127900 & 2 & 1 \\
\hline Badakhshan & 790200 & 9 & 2 & Daikundi & 383600 & 4 & 1 \\
\hline Takhar & 811700 & 9 & 2 & Jowzjan & 443300 & 5 & 1 \\
\hline Baghlan & 748000 & 8 & 2 & Kunduz & 817400 & 9 & 2 \\
\hline Samangan & 321500 & 4 & 1 & Kuchies & & 10 & 3 \\
\hline Balkh & 1052500 & 11 & 3 & TOTAL & 21677700 & 249 & 68 \\
\hline
\end{tabular}

Source: Independent Election Commission of Afghanistan (IECA). September 7, 2011.

50 Gopal, Anand. "Women lawmakers battle warlords", IPS ipsnews.net. http://ipsnews.net/news.asp?idnews=46028 Accessed June 15, 2011. 
The lack of significant improvement in women's representation and participation in political office is due to a number of reasons, including the threat of violence, worsened security, lack of adequate skills at the senior level, lack of support in Parliament and by the leadership, and cultural practices that negatively affect women. Furthermore, the lack of opportunities or programs focused on capacity building of Afghan women to work in senior positions in government severely limits the pool of women to choose as leaders in high positions. The lack of support in Parliament for women to qualitatively participate and the lack of serious support by the Afghan leadership contribute to a lack of significant change in women holding senior positions with meaningful contributions in governance.

In 2010, President Karzai nominated three women among his choices for ministers, but Parliament accepted only one of the women, Amena Afzali as Minister of MoLSAMD. A woman deputy minister, Sima Ghani, was also recently appointed to MoLSAMD. Currently, among the over twenty-five ministries and departments, three are headed by a woman minister. These include the MoLSAMD, the MOWA), headed by Acting Minister Husn Bano Ghazanfar, and the Ministry of Public Health (MPH) led by Dr. Suraya Dalil. Former women ministers have included Dr. Sohaila Siddiqi in the Ministry of Public Health and Masuda Jalal and Dr. Sima Samar as Ministers of MOWA.

\section{Women in Local Governance}

Data collected from the thirty-four provinces indicates that women play a very small, nearly negligible role in governance. Women involved in the government mostly consists of those working in provincial DOWAs. Beside the province of Bamyan, which has a woman governor, Habiba Sohrabi, women do not hold a lead role in decision-making in the Afghan provinces. Election laws stipulate that provincial councils must have one quarter of seats available to women. ${ }^{51}$ In some provinces there are women's shuras ${ }^{52}$, but decisions taken by these shuras are not given equal importance by men's shuras, who make the final decision on any community matter brought before the shuras. Furthermore, research revealed that there is a prevailing attitude that women should not delve into shura matters. In many instances, respondents were asked if there are women's shuras in their communities, and the response given was a simple 'yes'. Further questions on whether these shuras met and how involved the women are in the community revealed that in fact, women rarely take part in discussing or resolving community issues. In many areas, individual respondents wanted to show that their communities were open and equal minded toward men and women. This desire to seem more open-minded may be a positive indication of one day having open-minded policies within communities in the provinces.

\footnotetext{
51 Election Law. Translated by UNAMA and IFES. Accessible at http://www.iec.org.af/pdf/legalframework/law/ electorallaw eng.pdf

52 Shura is the Persian (Dari) word derived from Arabic for 'council'. The Pashto term 'jirga' also refers to the same thing in Afghanistan.
} 


\section{Peace negotiating teams}

Among the last official peace negotiation efforts in Afghanistan took place in 1988 with the Geneva Accords, where there were no women present in any of the signatory parties. This agreement did not confront the injustice done by the conflict parties against the Afghan population nor give any light on how grievances could be addressed in the future. ${ }^{53}$ The Bonn Agreement served to be the international community's quickly hatched up plan on how to broker a political settlement in the Afghan conflict. Again, meaningful attempts at addressing grievances of the Afghan population and key figures in the conflict, such as opposing parties, were left out of the process in Bonn.

Presently, Afghanistan does not have a formal peace negotiation taking place between government and insurgent groups. There has been coverage in the Afghan and international media that there are closed door negotiations taking place directly with Taliban and Afghan government entities, however, the Taliban have not ever directly confirmed or endorsed peace talks. ${ }^{54}$ With a lack of clarity on what is happening behind the scenes toward an end to the conflict, it is difficult to note whether there are women involved in any negotiating teams. However, considering the attitude of the negotiating parties toward women's participatory involvement in public affairs, it is unlikely women are attempting to negotiate a peace settlement with the Taliban.

While women may not be active participants of a settlement with the Taliban, they have met with some success in at least gaining seats at the tables discussing peace. In early June 2010, for the first time ever women took part in a peace forum, or peace jirga, along with men on the future of Afghanistan. The peace jirga aimed to build consensus on the approach to resolving the conflict in Afghanistan and allow for stakeholders to voice concerns and suggestions to the process. During the jirga, there was talk of ensuring the rights of women and other minorities in the peace process. ${ }^{55}$

\section{Figure 4:}

\section{Afghan Women's Resolution for Peace with Gender Justice ${ }^{56}$}

\footnotetext{
53 "Geneva Accords of 1988" Accessed February 25, 2011, from http://www.institute-for-afghan-studies.org/Accords \%20Treaties/geneva_accords_1988_pakistan_afghanistan.htm

54 "Taliban deny peace talks with West". Daily Times. July 7, 2011. Accessible http://www.dailytimes.com.pk/ default.asp?page=2011\%5C07\%5C07\%5Cstory_7-7-2011_pg7_5; "Taliban reject latest Karzai peace approach". Tolo News. September 29, 2010. Accessible http://tolonews.com/en/afghanistan/641-taliban-rejects-latest-karzai-peaceapproach-

55 Afghanistan Chapter Summary. Human Rights Watch. January 2011.

56 "Afghan Women's Resolution for Peace with Gender Justice". Afghan Women's Network (AWN). Statement Recommendations for the National Consultative Peace Jirga, June 2010.
} 


\begin{tabular}{|l|l|}
\hline 1 & $\begin{array}{l}\text { Each resolution that is against women's rights, and human rights in the peace jirga the women } \\
\text { Afghan women are collectively against. }\end{array}$ \\
\hline 2 & The peace jirga should not reject the achievements Afghan women have made in the past 9 years. \\
\hline 3 & $\begin{array}{l}\text { The participation of women in creating national policy and programs is important and must be } \\
\text { allowed. }\end{array}$ \\
\hline 4 & $\begin{array}{l}\text { The decisions and opinions of women regarding national policies and processes must not be } \\
\text { negated. }\end{array}$ \\
\hline 5 & $\begin{array}{l}\text { Each national program must contain } 30 \% \text { women. Each decision and national decision made without } \\
\text { the participation of women is unacceptable. }\end{array}$ \\
\hline 6 & Policies and laws without social justice and gender justice are unacceptable. \\
\hline 7 & Effective participation of women in the National Peace Jirga and Kabul Conference is necessary. \\
\hline 8 & $\begin{array}{l}\text { After the Peace Jirga, effective participation of women of every ethnic group must be included in } \\
\text { every discussion. }\end{array}$ \\
\hline 9 & Participation of women at 30\% is mandatory in every area. \\
\hline 10 & Women should participate in organizing every national program. \\
\hline
\end{tabular}

Source: Afghan Women's Network, Statement Recommendations for the National Consultative Peace Jirga, June 2010.

The National Consultative Peace Jirga as it is formally known consisted of approximately 21 percent women (about 334) and 80 percent men (about 1334) in total. Prior to this peace jirga, activists lobbied vigorously with national and international stakeholders, including the National Peace Jirga Commission, to increase women's participation from the original 12 percent to 24 percent. Women participants, making up the 21 percent of participants, spread themselves out across the various issue clusters formed during the jirga, managing to participate and voice out their concerns and ideas on the inclusion of gender and the challenges women face as Afghanistan works out a roadmap to peace.

Many activists hailed the peace jirga as a major achievement in women's efforts for equality and an important platform within the peace process in Afghanistan for women's voices. While the number of women in no way measured up to men's inclusion in the meeting, 334 women out 1,668 participants at a major national event in Afghanistan is seen as a milestone for many activists. At this jirga, women demanded protection of the gains they have made the past nine years should reconciliation with the current parties in conflict occur; national programs must contain 30\% women; participation and inclusion of women in creation of national policy and programs; women participant voices must not be negated based on their gender; and decisions and policies without social justice and gender justice are unacceptable. This list of recommendations gives a snapshot of the priorities of Afghan women activists as it relates to the shifting political and social dimensions within the country.

At the Kabul Conference which followed the peace jirga, women activists, as part of the large civil society sector, lobbied to be included in the proceedings and allowed a forum to present the concerns of Afghan women. Before this major international conference, activists from the 34 provinces met in Kabul to work out a platform indicating the issues they want highlighted by the government and the international community. Palwasha Hassan, a woman activist presented by Mr. Karzai for the position of Minister of Women's Affairs but not selected by Parliament, 
presented the civil society perspective at the Kabul Conference. ${ }^{57}$ At this conference, the Afghan and major world leaders in attendance together endorsed the reintegration of ex-Taliban fighters, with murmurs that women's gains would not be harmed.

Another development in peace efforts is the creation of the High Peace Council (HPC), which oversees the Afghanistan Peace and Reconciliation Program (APRP), created after the 2010 Peace Jirga as a government structure in support of negotiation with Taliban elements and tasked with creating guidelines for the government to reintegrate insurgents back into Afghan communities. It also oversees the creation of job and financial incentives for these ex-fighters so that they do not return to the Taliban or other insurgent groups. The HPC has the main role to structure the framework for high level talks with the Taliban. Interestingly, many members of this body were or are presently linked with groups who fought in the previous phases of the conflict. ${ }^{58}$ Recently, Burnuddin Rabbani, a former President of Afghanistan and mujahideen leader of Jamiat-e Islami, and head of the HPC, was assassinated in a suicide attack targeting him. While government sources claim the attack was led by the Haqqani network, it is unclear who killed him. Presently, the Karzai administration has said it is reconsidering peace talks with Taliban elements, and has suggested that it may be more logical to pursue peace talks with the state of Pakistan, rather than insurgent groups. From the Afghan perspective, insurgent groups operating in Afghanistan are supported by the Inter-Services Intelligence (ISI) agency, and conducting peace talks with these groups is futile so long as the policy of destruction comes from state elements. ${ }^{59}$ Peace talks with Pakistan may benefit women's rights as they would not be elements at the negotiation table. As a result of these events, work is on hold within the HPC and currently a review of the APRP strategy has started to determine whether peace efforts by Afghanistan will be facing insurgent groups or surrounding states.

Nationally, to the observing public, beyond holding seats as members of the HPC, it is unclear what the 9 women and 61 men in actuality do in furthering the peace process. The selection of women on the HPC seems to be symbolic in many ways, as most women on the HPC are not seen as representative of women's interests or effective advocates of women's rights. The extent of their effectiveness largely remains to be seen, but the 9 women of the HPC have worked throughout their first year as advocates of women in the peace process. There is a women's committee on the HPC that has recently been working on its strategic plan for the future. Nationally over the course of one year, they have held meetings with over 200 women, including those in the provincial HPCs.

\footnotetext{
57 The reason the Parliament did not vote for Palwasha Hassan is not wholly clear. Some in the press and Afghan circles speculated that because Ms. Hassan did not have experience in government.

58 Thomas Ruttig, “The Ex-Taleban on the High Peace Council: A renewed role for the Khuddam ul-Furqan?" Afghan Analysts Network, http://aan-afghanistan.com/index.asp?id=1248.

59 In 2010, after the arrest of Mullah Baradar, a top military commander of the Afghan Taliban, reports came out that the General Asfaq Parvez Kayani had offered to broker peace deals. See for example Jane Perlez, Eric Schmitt, and Carlotta Gall. "Pakistan is said to pursue foothold in Afghanistan". The New York Times, June 24, 2010, http:// www.nytimes.com/2010/06/25/world/asia/25islamabad.html?scp=1\&sq=haqqani\&st=cse.
} 


\section{Justice and Security}

During research on this indicator, challenges in accessing data from the relevant ministries proved to be daunting. Neither the Ministry of Justice nor Ministry of Interior were forthcoming in giving information on this indicator, despite numerous formal requests. Based on past research data, women make up few of positions at all levels in the justice and security sector. In 2007, out of 17, 314 police officers, only 93, or 0.53 percent were women. More recent data officially from the Ministry of Interior was not available. Data available through UNWomen makes it clear how little representation women have in the justice and security sectors. Overall, the two sectors are overwhelmingly men dominated.

\section{Figure 5:}

Percentage Participation of Women in Justice and Security 60
\begin{tabular}{|l|l|l|}
\hline \multicolumn{1}{|c|}{ Sector } & \multicolumn{1}{|c|}{ Women } & Men \\
\hline Police & 0.5 & 99.5 \\
\hline Military & 0.6 & 99.4 \\
\hline Judges & 4.7 & 95.3 \\
\hline Prosecutors & 6.4 & 93.6 \\
\hline Lawyers & 6.1 & 93.9 \\
\hline
\end{tabular}

Source: UNWomen (formerly Unifem) Factsheet 2010.

Based on previous information from the MOJ, in 2007, women held 4.7 percent of the seats out of 1,547 positions. According to figures obtained from MOWA, women in judgeship positions are still at 4.7 percent in 2010, but it is unclear based on figures obtained from the Ministry of Interior and Attorney General's office whether judgeships of women have declined or reporting has not counted all possible positions in 2009. With no quality quantitative data to compare these figures against, it is unclear how many women make up decision-making positions within these sectors. ${ }^{61}$

Information from the MOD was difficult to obtain this year due to the attack on the ministry early in the summer. After this attack all communication became difficult and the responsiveness

60 UNWomen (formerly Unifem) Factsheet 2010. Last Updated February 2010. Accessible http://www.unifem.org/ afghanistan/media/pubs/factsheet/10/index.html

${ }^{61}$ Attempts to gather information from the Attorney General's office were ended at the beginning when after some confusion, staff of the Loye Saranwal explained to the researcher that they were directed not to speak with anyone outside the office regarding any matters. The formal request to gather information from the Attorney General's office was denied thereafter. 
of the ministry to give out information declined to a standstill. As a result, there is no disaggregated data on women's participation within the military. Similarly, information from the MOJ was also difficult to obtain as it took two months of requests by the research team to receive data only through electronic means. Officials at the MOJ were faced with busy schedules or a lack of interest in the research and were not available for interview.

\section{Peacekeeping missions}

Afghanistan does not contribute to peacekeeping missions around the world, nor does it have a peacekeeping mission functioning in the country. The International Security Assistance Force (ISAF) is mandated under the UN Assistance Mission in Afghanistan (UNAMA) and led militarily by the North Atlantic Treaty Organization (NATO). Gender policies within the ISAF/ NATO effort in Afghanistan call for gender mainstreaming under the NATO BI-SC Directive 40-1, but the actual strategy is not clear as the Gender Annex (Annex X) of NATO policy is classified. ${ }^{62}$ The NATO directive posits gender equality key to sustainable peace and the gendered goal of NATO/ISAF in Afghanistan is to bring into place a commitment to gender equality without the continued help of ISAF.

The Provincial Reconstruction Teams (PRTs), headed in each area by a different NATO country, serve to bring security and micro-level development to the provinces. They engage with the population through these development programs but very little with local women. In the same way that PRTs are pre-dominantly male, the Afghans these teams come into contact with are male as well. Afghan women as a result have very little interaction with non-combat elements of the NATO/ISAF mission in Afghanistan. In cases when help is sought through the PRTs, women who face violence or other harm, are given referrals as it is not a part of the PRT mandate to help these women with direct services. As a new part of the US Marine Corp counterterrorism strategy, certain PRTs have established Female Engagement Teams (FETs), which are femaleonly teams with the objective of engaging local women. The FETs are independent of ISAF command, with 16 US Marine Corp FETs around Helmand Province and 4 under British command and possibly more to come. ${ }^{63}$

\section{Constitutional or Legislative Review}

On laws such as Elimination of Violence against Women (EVAW) and the Shia Personal Status Law, women have participated more than men in reviewing and reforming the proposed versions

\footnotetext{
62 Presentation on NATO/ISAF Gender Guidelines. Women, Peace, and Security Cluster Group Meeting, Kabul, Afghanistan. 13 March 2011.

63 "Engaging Women on the Frontline" ISAF-International Security Assistance Force. http://www.isaf.nato.int/article/ focus/engaging-women-on-the-frontline.html. Accessed August 12, 2011.
} 
of the laws. This is simply because laws that directly affect women have managed to get more attention from women advocates who more readily lobby on issues affecting women with the MOJ, the Parliament, and the Office of the President. Numerical data on the participation of women in legislative review is unclear as the process of legislative review goes through Parliament, the Ministry of Justice, and civil society lobby groups. Laws and policies that originate in the Ministry of Justice has a review committee which reviews and sends a proposed bill to the Ministers Council after which it is sent to the Parliament. ${ }^{64}$ In theory, the process of legislative review must look at each bill as compliant with the Afghan Constitution, Islamic Sharia, and international human rights commitments. However, a number of bills have passed through this process that severely condense the rights of women, such as the Shia Personal Law, as well as other laws that infringe on the rights of all Afghans, such as the draft bill on "Prevention of extravagance in wedding ceremonies", which has many provisions that echo the edicts of the Taliban Vice and Virtue wing. ${ }^{65}$

Constitutional review in Afghanistan can only happen under the auspices of a Loya Jirga ('grand jirga'), which is a large gathering of community elders, tribal, and other interest groups. In the creation of the Afghan Constitution, a Constitutional Loya Jirga was held in December 2003, where 500 delegates debated and decided upon the prepared draft of a constitution. Women made up 64 delegates to the Constitutional Loya Jirga, with an additional 25 appointed by President Karzai. Women participants at this jirga like Malalai Joya, Masooda Jalal, and Palwasha Hassan were among the woman mobilizers fighting for the rights of women to be enshrined in the constitution. Among the major wins for women in the Constitution Loya Jirga was gaining 25 percent of 250 seats in the Lower House, and 50 percent of presidential appointees to the Upper House of the National Parliament.

\section{CSOs in Task Forces on SCR 1325 and 1820}

Currently, there are several civil society groups involved in giving awareness on the UN SCR 1325 and the creation of a national action plan. Early discussions with key implementing ministries such as MOFA and MOWA have included these groups and in the coming year continued involvement of civil society groups is expected at the planning table. Information on how involved civil society organizations, especially women's organizations, are on UN SCR 1325 and 1820 is inconclusive. Most organizations who were given surveys on their activities related to UN SCR 1325 and 1820 did not respond. The few that did respond are not enough to posit a clear picture of where CSOs stand as it relates to UN SCR 1325 and 1820.

\footnotetext{
64 How many women may be on this review committee within the ministry was left unclear due to a lack of availability from the MOJ for an interview.

65 Interview with Afghan human rights activist and lawyer. Kabul, Afghanistan. August 27, 2011
} 


\section{B. PREVENTION and PROTECTION}

\section{Sexual and Gender-based Violence (SGBV)}

Rape, sexual violence, assault and harassment are not topics that are openly discussed in Afghanistan. Due to a culture of honor and shame, negative or hostile attitudes toward victims of these crimes, and the reign of impunity, women and girls have very little access to help and support from their families or from the justice and security sectors. From informal discussions with women who have lived through all phases of the conflict, it is clear that rape and sexual violence or the threat of either have been a part of the experience of war for Afghan women. Women's survival during the conflict often included the fear of and tactic to fend of possibilities of rape or kidnapping by militia soldiers or even members of a community. During conflict, rapists and other violators acted with impunity. Rape and sexual violence outside of the conflict continues to occur without much chance of the perpetrator being arrested or tried for his crime. As a signatory of the Rome Statue on the International Criminal Court, in Afghanistan rape and sexual violence during violent conflict must be seen as crimes against humanity and prosecuted as such. Former fighters and militias guilty of these crimes must be brought to justice through a TRC or other context conscious mechanism.

Since 2007, gender based violence and threats against women have increased on at an alarming scale. Threats against women and girls who attend school or work outside the home have not only increased, but have resulted in attacks and deaths. The Taliban and other elements seek to limit not only women's movement, but also voices for speaking out against what ails Afghanistan. Zakia Zaki, a radio journalist at Sada-e Solh (Voice of Peace) radio, was shot dead in her sleep in Jabal Saraj, Parwan Province in 2007. Her on-air criticisms were both against the Taliban and former mujahideen. Others who did not give up in their work or in the belief for a better future for Afghan women and were killed include brave women like Safia Amajan, Sitara Achakzai, and Malalai Kakar. ${ }^{66}$

As with the increase in violence and threats against women, overall security in the country has worsened in recent years. As the conflict has worsened, women have especially been affected as they are among the most vulnerable of groups in the country. With any increase in violence, the most vulnerable groups bear the brunt of violation and abuse.

Women who suffer sexual or gender based violence are among the faceless and voiceless. Women and girls who are victims of SGBV often do not approach authorities out of fear and shame. Many who do complain often end up blamed and vilified for their victimization. Police and the justice system inadequately pursue and prosecute perpetrators. In August 2008, President Karzai showed just how the highest office in Afghanistan views violence against women and illustrated the inadequate effort by authorities. After the Supreme Court convicted and sent to

\footnotetext{
66 For more on attacks against women in the public sector, review the December 2009 report by Human Rights Watch, highlighting women's rights in Afghanistan. "We have the promises of the world". Human Rights Watch. December 2009. Accessible http://www.hrw.org/en/node/86805
} 
prison three men for the rape of a woman in the northern province of Samangan, Karzai quietly pardoned the three. Often, the burden of proof rests on the victim and both the attitude of authorities and society forces women to keep silent or receive no justice. Cases of rape are often hard to prove since in Afghanistan, a victim needs four witnesses to the crime. Often, women are accused of zina, or adultery, when they lodge complaints of rape, or they are ignored or abused by authorities.

Despite attempts to get data from the Ministry of Interior and the Ministry of Women's Affairs, new information on the actual number of cases brought before police could not be obtained. Previous data reveals that the largest number of cases of gender based violence is physical violence. In 2005 and 2006, the Ministry of Interior recorded 2,133 cases of gender based violence that were reported, investigated, prosecuted and punished, of which 1,011 were cases of physical violence against women. For this period, only 33 cases of rape, 10 cases of bad and badal of girls, 5 cases of trafficking, and 87 cases of murder were recorded.

Figure 6:

Sexual and Gender-Based Violence67:

Cases successfully investigated, referred, prosecuted, and penalized

\begin{tabular}{|l|l|l|}
\hline \multicolumn{1}{|c|}{ Types of Case } & \multicolumn{1}{|c|}{ Total Women Victims } & Percentage of Cases Over Total \\
\hline Physical Violence & 1011 & 47.4 \\
\hline Forced Marriage & 769 & 36.1 \\
\hline Non-support by husband & 100 & 4.7 \\
\hline Murder & 87 & 4.1 \\
\hline Abuse & 69 & 3.2 \\
\hline Sexual Abuse or Rape & 33 & 1.5 \\
\hline Kidnapping & 24 & 1.1 \\
\hline Denial of property by in-laws & 20 & 0.9 \\
\hline Bad and badal kardan & 10 & 0.5 \\
\hline Trafficking & 5 & 0.2 \\
\hline Theft by women & 3 & 0.1 \\
\hline Denial of inheritance & 2 & 0.1 \\
\hline Total & 2133 & 100.0 \\
\hline
\end{tabular}

Similarly, data from 2008 (Figure 4) and 2009 (Figure 5) reveal the most cases of SGBV cases are classified as zina, followed by murder and physical violence. Rape cases in both years are under 100. This data may be telling of the way rape cases are handled and viewed in Afghanistan. Not only is it hard to prove rape in Afghanistan, where four witnesses are required in a court, but women and girls also fear speaking out due to the cultural taboo on sexual relations outside of marriage. Cultural sensitivity forces these women and girls to be seen as the instigators for their rape, and women who are rape victims are first seen as tainted objects of

\footnotetext{
${ }^{67}$ As reported by Ministry of Interior in 2010 to AWN. New data on these cases were not available upon request from the MOI or from MOWA. This data is however vague and gives very little clear information on cases, victims, and how these cases go through the system.
} 
family honor, not as victims of a crime against their human dignity. When rape cases cannot be proven, which is often, women may be punished for zina, or adultery, and imprisoned for moral crimes. Available data shows the highest number of reported, investigated, and punished cases to be of adultery.

Figure 7:

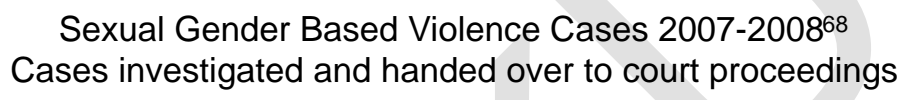

\begin{tabular}{|l|l|l|l|l|l|}
\hline $\begin{array}{l}\text { Type of } \\
\text { Case }\end{array}$ & Number & Woman & Girl & Total & $\begin{array}{l}\text { Occurrence } \\
\text { of Arrest of } \\
\text { Perpetrator } \\
\text { in the Case }\end{array}$ \\
\hline Rape & 56 & 40 & 18 & 58 & 101 \\
\hline $\begin{array}{l}\text { Zina } \\
\text { (adultery) }\end{array}$ & 314 & 394 & 0 & 394 & 406 \\
\hline Murder & 130 & 90 & 0 & 90 & 275 \\
\hline Kidnapping & 37 & 40 & 0 & 40 & 60 \\
\hline $\begin{array}{l}\text { Physical } \\
\text { Violence }\end{array}$ & 120 & 103 & 18 & 121 & 158 \\
\hline $\begin{array}{l}\text { Trafficking } \\
\text { Self- } \\
\text { immolation }\end{array}$ & 1 & 1 & 0 & 1 & 1 \\
\hline Total & 693 & 8 & 0 & 8 & 9 \\
\hline
\end{tabular}

Figure 8:

Sexual Gender Based Violence Cases 2008-200969 Cases investigated and handed over to court proceedings

${ }^{68}$ As reported by Ministry of Interior in 2010 to AWN. New data on these cases were not available upon request from the MOI or from MOWA.

${ }^{69}$ As reported by Ministry of Interior in 2010 to AWN. New data on these cases were not available upon request from the MOI or from MOWA. 


\begin{tabular}{|l|l|l|l|l|l|}
\hline $\begin{array}{c}\text { Type of } \\
\text { Case }\end{array}$ & Number & Woman & Girl & Total & $\begin{array}{l}\text { Occurrence } \\
\text { of Arrest of } \\
\text { Perpetrator } \\
\text { in the Case }\end{array}$ \\
\hline Rape & 71 & 43 & 28 & 71 & 95 \\
\hline $\begin{array}{l}\text { Zina } \\
\text { (adultery) }\end{array}$ & 404 & 740 & 0 & 740 & 938 \\
\hline Murder & 230 & 179 & 19 & 198 & 259 \\
\hline Kidnapping & 70 & 38 & 0 & 38 & 90 \\
\hline $\begin{array}{l}\text { Physical } \\
\text { Violence }\end{array}$ & 131 & 106 & 25 & 131 & 163 \\
\hline Trafficking & 0 & 0 & 0 & 0 & 0 \\
\hline $\begin{array}{l}\text { Self- } \\
\text { immolation }\end{array}$ & 72 & 59 & 0 & 59 & 22 \\
\hline Total & 979 & 1169 & 72 & 1237 & 1567 \\
\hline
\end{tabular}

Figures 7 and 8 contain information obtained from the MOI on official figures of SGBV in 2007-2008 and 2008-2009. However, based on the information AWN obtained from the ministry, it is unclear whether many reported cases have single or multiple perpetrators. Often it is possible that many cases involve single or multiple victims, as well as single or multiple perpetrators.

It must be mentioned that these three charts contain information obtained from the MOI that is vague and can be misleading. According to the MOI, this is the sort of information available on cases of SGBV. What these charts essentially claim is that the justice and security sector is actively working on combating impunity for crimes against women. However, based on this information it is difficult to ascertain that the information is an accurate picture of the response on SGBV cases. Furthermore, while researchers were told for example that the data presented in Figure 5 is a breakdown of cases that were reported, referred, prosecuted, and penalized, it is more likely that the data is simply on cases that were reported in 2008. Figures 6 and 7 speak of the arrest of perpetrators related to the cases, but do not have information on whether these cases were eventually prosecuted and penalized. Researchers repeatedly requested specific data on SGBV cases from the MOI and MOWA, but were unable to obtain clear and concise quantitative data. One major problem that seems to face ministries is their incapacity or lack of attention to proper gathering of disaggregated data on issues of concern and being able to readily share this information with the public. The overall low numbers imply that reporting and recording of cases occurs dismally and ineptly, victims do not come forward to report or purse cases, or that authorities do not take these cases seriously and fail to properly record cases.

In the cases recorded by the Afghan Independent Human Rights Commission (AIHRC), physical violence is again the most frequent of cases, along with other forms of abuse such as denial of food, and forced marriage. Running away from home is also counted here, though the reasons for running away or if a girl or woman has simply left an abusive home are unclear based on this 
data. Often, women and girls who go to police stations or other authorities to escape abuse or forced marriages are labeled as runaways, both undermining their own victimization and making it easy for the authorities to do nothing.

\section{Gender responsive laws and policies}

Fair and adequate protection of women and girls from violence and abuse and prevention through laws and policies is substantially lacking in Afghanistan. While there are a few genderresponsive laws and policies, implementation is in the hands of a largely indifferent and often hostile justice and security sector. One specifically gender-responsive law is the Elimination of Violence against Afghan Women (EVAW), passed through a presidential decree in July 2009 while Parliament was out of session, and still not officially passed by Parliament. In September 2011, the Commission on Women's Rights, a cluster within Parliament headed by Member of Parliament, Fawzia Koofi, sent a revised version of the EVAW Law to Parliament, where members must vote in both houses on the changes. ${ }^{70}$ Changes have come in Article 42, which stated that no one can postpone, pardon, or mitigate the punishment of those convicted of crimes under the EVAW law. According to the Constitution, the President has the authority to forgive punishment of crimes and this is violated under Article 43.

The objective of EVAW is eliminating "traditions and practices that cause violence against women contrary to the religion of Islam...[and] prosecuting perpetrators of violence against women". ${ }^{71}$ This law makes rape a crime for the first time in Afghan history and criminalizes many other negative cultural practices. ${ }^{72}$ Women have the right to seek protection, emergency health services, confidentiality, and prosecution of the perpetrator. Convicted rapists are to be sentenced to life imprisonment if their victim lives, and to the death penalty if their act of rape results in the death of the victim. Access to justice for women is tremendously strengthened through the EVAW law and government bodies are made responsible to serve as protective and supportive groups for Afghan women. ${ }^{73}$

Currently, a draft law that attempts to bring the decisions of local shuras into legal recognition is under review in the MOJ. Previously, attempts at bringing the informal courts into recognition was voted down by Parliament. This new draft law has been submitted by provincial councils in

\footnotetext{
70 Telephone communication with office of MP Fawzia Koofi, September 29, 2011. Kabul, Afghanistan.

71 Elimination of Violence Against Women (EVAW) Law, Chapter 1, General Provisions. Article 2.

72 lbid., Articles 3, 4, and 5.

73 Among the practices committed against women and criminalized under the EVAW law are acid or poison attacks, forced prostitution, injury or disablement (as a result of physical violence), buying and selling of women and girls, the practice of bad or badal kardan, forced marriage, under-age marriage, forced drug addiction, forced suicide or selfimmolation or creating conditions so that a woman or girl commits these acts, preventing possession of inheritance or acquiring property, preventing access to work or school, and taking on more than one wife without adhering to the Civil Code
} 
an attempt to formalize the decisions made by local community gatherings. Decisions can be on any types of conflict, including those that involve women or one in which women have major grievances. The formalization of these social structures with legally binding decisions will ultimately short change women, who tend not to use or attend local shuras. Furthermore, as a male domain, local shuras leave out or ignore the voices of women and dominate the process. When the process is flawed at the outset, it is hard to imagine women getting a fair chance in front of local shuras.

General policies that are gender responsive include the Afghan Constitution, the National Action Plan for Women of Afghanistan (NAPWA), and the Afghan National Development Strategy (ANDS). These documents and policies reflect the dual nature of the state of women's rights in Afghanistan. Women have their rights protected by official foundational documents, but are denied the same rights through the lack of mechanisms to enforce or implement their realization. Furthermore, most Afghan women and men are unaware of the rights that protect them in policies and laws.

For the lack of clearly implemented gender responsive laws and policies, there are a number that are harmful and reductionist to the rights of Afghan women. Among these laws is the Shia Personal Status Law, which, after much controversy and revision, still marginalizes the rights of Shia women, including giving child custody to fathers and grandfathers only and making it legal for a husband to control the movements of his wife, despite the fact they run counter to rights of women protected by the Constitution and other laws.

Women have the right to work and the right to three months of maternity leave according to the law on work. In February 2011, the government attempted to bring women's shelters under its fold and not allow private run, non-governmental shelters to operate in the country. Among the reasons for these government efforts were claims that non-government groups could not make proper use of funds for these shelters. ${ }^{74}$ These efforts were to a successful degree thwarted, but shelters must abide by regulations uniform across the country and MOWA has the responsibility of monitoring these shelters. Had the government been successful in its campaign, women and girls seeking aid and protection from shelters would have been subjected to dehumanizing panels where they would have to make their case and forensic exams prior to being helped. The provisions of the regulation on shelters, which was approved by the Cabinet, focus on the staffing and workings of shelters, and require that shelters must be registered with the government and be ready for monitoring by MOWA at any time. AWN and other civil society activists pressured the MOJ, MOWA, and the Office of the President to pass the regulation without transferring responsibility of shelters to the government and denying women's groups from supporting women and girls in distress.

\footnotetext{
74 "Afghan activists condemn women's shelter takeover plans." BBC News. February 17, 2011. Accessible http:// www.bbc.co.uk/news/world-south-asia-12492165; "Afghanistan defends takeover of women's shelters". Reuters. February 15, 2011. Accessible http://www.reuters.com/article/2011/02/15/us-afghanistan-women-idUSTRE71E2K320110215; "Afghan women fight back, preserve shelters". NPR. September 26, 2011. Accessible http://www.npr.org/ 2011/09/26/140709134/afghan-women-fight-back-preserve-shelters.
} 
In this way, civil society and specifically women's and human rights activists have continued to advocate for positive recognition of women's rights in other draft laws and proposals of policy. The EVAW law was largely influenced by civil society activism, even though its proposed changes and overall process was facilitated by the MOWA. Currently, activists are on alert about a draft law on recognizing shura councils as government recognized venues for addressing community or family problems. Should this draft law, currently in the MOJ, find acceptance, attempts at formalizing the informal justice mechanism will be strengthened. This draft law comes after many months of lobbying by civil society groups with the government to not recognize the informal justice system as a valid alternative to the federal courts.

Laws and policies that protect and promote women and girls are useless when these individuals do not know their rights and how to make use of them. Women face barriers to their rights, and gender responsive policies and laws go only as far as officials in government, Parliament, the formal justice system and cultural biases allow. Support for gender responsive policies has been meager in many areas of government, especially in Parliament, within which there is a majority conservative element that pushes for laws and polices that undermine the equalizing spirit of the Constitution, Islamic law, and international human rights values.

\section{Truth and Reconciliation Commission (TRC) and other transitional justice}

Transitional justice in Afghanistan is not set in a formalized structure under a truth and reconciliation commission (TRC). The Afghan people have not been asked how they want to continue toward peace in regard to crimes committed by commanders, soldiers, whole militias, and communities against one another during the violent conflict. The violence faced by all communities, individual deaths, or massacres have not been addressed or punished by the Afghan government and there has not been any serious effort on the part of the international community.

In 2004, the Afghan Independent Human Rights Commission (AIHRC) produced the report, "A Call for Justice", profiling citizens' desire for national accountability of human rights abusers and violators. ${ }^{75}$ According to the report, up to 70 percent of Afghans surveyed claimed to have suffered or had family who suffered from loss and injury during the conflict. ${ }^{76}$ Based on the findings of this report, the commission worked with a three-member panel, the Office of the President, and the United Nations Mission in Afghanistan (UNAMA) to create a four year, five point action plan for the implementation of a national strategy on peace, reconciliation, and justice. This strategy, entitled the "Action Plan of the Islamic Republic of Afghanistan for Peace,

\footnotetext{
75 "A Call for Justice". Afghanistan Independent Human Rights Commission (AIHRC). Report Accessible www.aihrc.org.af/Rep_29_Eng/rep29_1_05call4justice.pdf

76 Ibid. p. 45
} 
Justice, and Reconciliation" was adopted by the Karzai cabinet in late $2005 .{ }^{77}$ The action plan calls attention on five key areas: 1) acknowledgement of suffering through memorial, 2) ensure credible and accountable state institutions and purging human rights violators and criminals from the state institutions, 3) truth-seeking and documentation, 4) promotion of reconciliation and improvement of national unity, 5) establishment of effective and reasonable accountability mechanisms. ${ }^{78}$

Not only did this particular action plan expire without a formal extension, it has been contradicted and ignored by the formalization of an amnesty bill approved by the Parliament and President in 2007 and made official by appearing in the government gazette in 2009 . Now formally law under the title the "National Reconciliation, General Amnesty and Stability Law' (hereafter Amnesty Law), it forgives crimes committed during the conflict period by those currently in government. While this Amnesty Law is meant to support and strengthen reconciliation, it ends up giving a blanket amnesty to all responsible for crimes during conflict and cheats victims their right to justice and accountability. ${ }^{79}$

The creation of the High Peace Council and the APRP Joint Secretariat has not triggered a formal transitional justice program as part of the APRP. Transitional justice, thus far, has been geared toward reintegrating former fighters into Afghan communities. There has been no significant effort to answer to the crimes committed against civilians by individuals or parties tied to the Communist, mujahideen, or Taliban eras of the conflict.

\section{Gender and peace education}

Gender and peace education is not formalized in any meaningful way into the curriculum of schools in Afghanistan. This means that children in grammar and middle school or in high schools across the country do not receive schooling that also factors in for example, how to resolve personal conflict, the values of peace, the ill effects of violence, the equality between men and women, and the rights of men and women as Afghan and human citizens. According to school officials in the provinces, elements of peace may be taught in some schools, however, gender education is not practiced. School officials from across the provinces noted that peace and gender education were not a part of the government run school curriculum.

\footnotetext{
77 "President Hamid Karzai launches the action plan of the Islamic Republic of Afghanistan on peace, justice and reconciliation". ReliefWeb. December 12, 2006. Accessible http://reliefweb.int/node/221009

78 "Action Plan of the Islamic Republic of Afghanistan for Peace, Justice, and Reconciliation". Government of Afghanistan. Accessible http://www.norway.org.af/NR/rdonlyres/ C9F4CAAC24814924BA760231E37D9BC5/72001/070109TJHandlingsplanenpdf.pdf

79 "National Reconciliation, General Amnesty and National Stability Law". Afghan Analysts Network (AAN). Unofficial translation accessible http://aan-afghanistan.com/index.asp?id=665
} 


\section{PROMOTION OF A GENDER PERSPECTIVE}

The international community and Afghan actors who met in Bonn in 2001 came together to call for an end to the violent conflict in Afghanistan, usher in democratic tenets as a way to rebuild Afghanistan, and guarantee human rights and women's rights in particular. After the Bonn Agreement and the creation of the provisional government of Hamid Karzai, the Afghan government voiced its commitment to include the voices of all Afghans in rebuilding the country, including that of Afghan women. The rebuilding and development agenda of donor nations shared the same tone as the agenda of the NATO nations who claimed to be liberating Afghanistan from the Taliban to respond to the trampling of women's rights. Afghan women's rights became the rallying cry for both the Coalition of the Willing, media covering Afghanistan, and development agenda.

There is no functioning peace agreement in Afghanistan. While many areas are relatively peaceful, the violent conflict still continues in the areas bordering Pakistan and slowly encroaching toward Kabul as insurgents gain control of provinces surrounding Kabul province.

According to the MOI, police receive trainings that incorporate international commitments, human rights principles, and gender. The number of trainings or programs was not made clear to researchers but we were initially promised further data. However, specific data on the number and nature of these trainings failed to be shared by the MOI with the researchers.

Despite attempts at surveying at least women's civil society organizations on this indicator, researchers were not successful in obtaining enough data to give a meaningful report. Civil society organizations seemed too busy or untrusting of the motives of the research by AWN to take part in the survey that would give information on their allocated and disbursed funding for WPS programs. Part of the challenge facing activists and civil society organizations is a lack of trust and cooperation on shared struggles.

Data on most indicators was difficult to obtain from government ministries. Information regarding budget and funding was not shared in any direct way. Instead, a few ministries, such as MOWA, that were willing to give out information mentioned projects that were implemented in the provinces but would not state the amount of funding these projects required and were given.

Finding data on women's representation in media content required surveying over three dozen radio and television stations as well as countless newspapers and magazines in Kabul alone. For the time being gathering information on the percentage of women's representation in media content as peace-builders or decision-makers was severely limited due to monetary and staff 
resources. This is an area of research that is lacking information from government sources, including the Ministry of Culture and the Central Office of Statistics, as well as media focused civil society groups.

\section{Conclusions and recommendations}

\section{Concluding Remarks}

Afghan women's participation in the areas of governance, security, peace and justice has certainly expanded since 2001. However, there are extensive gaps in how much access women have to positions with influence and decision making power, to safety and security at the most basic level. Similarly, protection from and prevention of violence and abuse against women and girls has been incorporated into the body of the Afghan Constitution. Despite this, women and girls continue to face violence and abuse at the hands of family, community members and or people affiliated with the parties in conflict.

Improvement of the situation of Afghan women must be set through relevant and mindful priorities that take into account the needs and concerns of a wide range of women and girls. Most importantly, the focus cannot be on just one area concerning women. Instead, vulnerable women, educated, uneducated, rural, and urban women must be brought into the fold of social life through opened space for their voices and needs. Key to this is women's participation in decision and policy making, approaches to peace and governance, and legislation. Protection and prevention of violence against women and girls must be made a real priority, including through stance on impunity against those who violate and abuse women and girls. The inclusion and transmission of a gender perspective through the curriculum, as well as through informal means of education, also stand as the key to improving the gender issues landscape of Afghanistan.

Acknowledging the great strides Afghan women have made in the past 10 years, the national and international commitments of the Government of Afghanistan to Afghan women, and in the unwavering belief that without the inclusion, participation, protection, and promotion of half the population the way to peace and development will never succeed, this report offers the following recommendations to the Government of Afghanistan, Afghan civil society, actors in the peace process, and the international community:

\section{Recommendations}

\section{To the Government of Afghanistan}




\section{Office of the President}

- Ensure that the protection of women's rights in the peace, reintegration, and reconciliation processes are part of the central discussions.

- Urge the Parliament to support the EVAW law implementation without further delay.

- Support the time bound implementation of NAPWA.

- Advance justice by publicly committing to a timeline for the Action Plan for Peace, Reconciliation, and Justice.

- Ensure that Afghan women play an active role in the Bonn Conference in December 2011, including shaping the agenda and outcome of documents.

- Ensure that 30 percent of the Afghan delegation to the Bonn Conference is composed of civil society, half of which must be women.

- Publicly condemn attacks on women and girls.

- Publicly condemn attacks on education, girls students, and women teachers.

- Ensure women are appointed to key roles in governance, justice, and security sectors.

- Continue in strengthening a national security strategy that is also consistent with Afghanistan's international commitments on UN Security Council Resolutions (1325, 1820, 1888, 1889, and 1960) concerned with women's rights and conflict.

- A National Action Plan on UN SCR 1325 should be integrated as part of the national security policy, ensuring the representation of women in all peace and security deliberations and decisions through a quota system.

- Act on the commitments made October 26, 2010 at the Security Council Open Debate regarding UN SCR 1325 and its subsequent related resolutions (1820, 1888, 1889, and 1960) by supporting the creation of a National Action Plan on UN SCR 1325 for Afghanistan.

High Peace Council and the Afghanistan Peace and Reconciliation Program (APRP)

- Ensure that peace efforts do not destroy achievements and gains in women's rights as Afghanistan seeks an end to the ongoing conflict.

- Ensure that women, youth, and wives and family members of former fighters are included in the peace process at the provincial level.

- Develop a system where victims of the conflict can register their grievances as the peace process goes forward.

- Consult with women and create space for them to serve as active participants to all national peace and reconciliation, reintegration, and transition processes.

- Ensure women representatives from the village and district level councils play a key role in the peace and reconciliation, reintegration, and transition processes.

- Demand the end to attacks and intimidation of education sites, girl students, and women teachers when negotiating with insurgents and former fighters.

Ministry of Women's Affairs

- Advocate for and support women and girls who face domestic violence, sexual violence, rape, harassment, and intimidation by providing improved systematic attention and registration services by MOWA and DOWA staff. 
- Improve capacity and sensitivity of MOWA and DOWA staff to adequately support women and girls seeking help.

- Create monitoring mechanisms on the EVAW law and SGBV and a working registration process in each province and each district on violence against women and SGBV cases. Train the staff with effective methods so that they can give full and honest attention to each case.

- Raise awareness among men and women in all 34 provinces, with specific focus to non-urban areas and a targeted plan on the EVAW law, rights of women under Afghan law and Islamic law, and importance of women's education to the community and to the family.

- Work with Ministries of Interior, Public Health, and Education to build a coordinated system focusing on the access to emergency health services, psycho-social support, information on what to do and where to go in case of violence or rape, and access to safe shelter.

- Improve gathering and providing disaggregated data regarding women and girls and education, health, SGBV, forced marriage and other negative cultural practices, self-immolation and other suicide, and participation in the public sector, among other topics.

- Establish a reintegration cell within the ministry and through the Joint Secretariat Committees engage with the implementation of the Afghanistan Peace and Reconciliation Program (APRP).

- Gather sex-disaggregated data through the APRP monitoring and evaluation units at the provincial and national levels.

- With the Ministry of Foreign Affairs, support the creation of a national action plan for Afghanistan on the implementation of UN SCR 1325 and its subsequent related resolutions UN SCR 1325 and its subsequent related resolutions (1820, 1888, 1889, and 1960).

\section{Ministry of Interior}

- Improve training of police, in urban and rural areas, to respond to domestic violence, sexual and gender based violence, rape, and other types of cases with objectivity and according to the law.

- Focus on improving the attitudes of police by teaching respect toward women as an Islamic and Afghan value and code of conduct.

- Expand the Family Response Units into every district police station of the 34 provinces.

- Improve the Family Response Units by hiring more female officers and giving training on objective and responsive methods.

- Focus on recruitment of women into policing and security through coordination and collaboration with Ministry of Women's Affairs and women led organizations to support and encourage families to allow the women and girls in their families to join the ANSF.

- Increase the number of women police officers, including the number of women prison guards.

- Improve protection measures for women in Provincial Councils and Provincial Peace Councils and the Provincial Joint Secretariat Team members.

- Improve criteria for recruitment to the ANSF, excluding those individuals against whom there are allegations of violence or other abuses against women.

- Investigate attacks on education sites, students, and teachers and push for prosecution of perpetrators with the Office of the Attorney General and MOJ.

\section{Ministry of Foreign Affairs}


- Initiate the creation of a national action plan for Afghanistan on the implementation of UN SCR 1325 and its subsequent related resolutions UN SCR 1325 and its subsequent related resolutions (1820, 1888, 1889, and 1960).

- Ensure that all related ministries, civil society groups, and ordinary women in the provinces are included in the creation of NAP.

- Support a comprehensive NAP by creating open dialogue at the district and even sub-district levels between women across the country and MOFA and MOWA to obtain the experiences, concerns, and challenges of ordinary Afghan women and create a comprehensive and allinclusive NAP.

- Support the implementation of commitments toward women's rights made in international forums, such as the London and Kabul Conferences, and commitments incumbent upon Afghanistan through international conventions and resolutions.

Ministry of Public Health

- Create support programs for women and girls where they can receive emergency treatment and other free services.

- Collect disaggregated data on women and girls, especially those who face SGBV, domestic violence, rape, self-immolation or other suicide, and those who cannot continue their education.

\section{Ministry of Justice}

- Ensure that women and girls who face physical, sexual, gender based violence, rape, and other harm receive assistance through the justice system.

- Increase the number of women lawyers, judges and law enforcement women staff who can specifically focus on the needs of women who are victims.

- Ensure that the law on marriage requires the presence of the husband and wife upon registration of the marriage.

- Ensure the draft bills that come up for review are in line with the Constitution, Afghan law, and international human rights standards.

- Create and implement training and awareness programs with the Ministry of Interior for police and other law enforcement on the rights and protections owed to women by the law; train and give awareness to judges on the rights and protections owed to women by the law as well as the difference between objective judgement and judgement ruled by cultural beliefs of the judge and prosecutor.

- Initiate a review of concepts such as "running away" which is not a crime but women are imprisoned and punished for committing.

\section{Ministry of Information and Culture}

- Focus on raising awareness through media programs on importance of girls' education, family violence against women, self-immolation, women's rights under Afghan and Islamic laws, and how women can receive support and help in case of emergencies.

- Work with the Ministry of Education and Higher Education in raising the peace potential of students by giving awareness on gender and peace. 
- Gather disaggregated data on representation of women in Afghan media, and possible improvements.

Ministry of Education and Higher Education

- Continue to work on and improve efforts in absorbing girls into the education system by increasing the knowledge of families, communities, and religious leaders on the importance and pivotal role girls' education has on the community and family, and the traditional Islamic value toward education.

- Include peace and gender education as part of the school curriculum; give awareness on the rights of women and girls, including the right to choose a marriage partner as based on Islam, the crime of child and forced marriage, and other provisions of protection under the law.

- Prioritize recruitment and training of women teachers and expand the number of classes and schools for girls, including segregated schooling to improve access to schooling for girls especially in conservative communities.

\section{Ministry of Hajj and Pilgrimage}

- Train and give awareness of religious leaders and teachers and mullahs at Friday sermons to support women's rights under Afghan law, linking these rights with Islamic law and Islamic cultural history.

- Work with the Ministry of Information and Culture to build awareness programs on the rights of women under Afghan law and Islamic law.

\section{To Afghan Civil Society Actors}

- Continue to advocate and lobby for the full implementation of women's rights as enshrined by the Constitution and Afghan law.

- Work with government bodies such as Ministries of Justice, Women's Affairs, Interior, and Public Health, among others, to strengthen the protection and prevention violence and abuse against women and girls.

- Work with community shuras including men, women, and religious leaders and teachers to raise awareness on the rights of women, violence, and abuse against women.

\section{To the International Community and Donors:}

- Support Afghan civil society and women activists in particular by pressing on the Afghan government to include their voices on policies, participation at the decision-making table, and key concerns on the peace, reintegration, and reconciliation processes.

- Support the GoA in implementation of the NAPWA, EVAW, and other positive gender policies.

- Support and strengthen programs that provide capacity building and technical assistance to the justice and security sector in better implementation of protection and prevention of violence and abuse of women and girls.

- Support Afghan women's groups, the AIHRC, other human rights groups, and Afghan civil society to be a voice in bringing peace and justice.

- Support women's groups through financial and technical resources to expand participation in the peace process in the provinces. 
- Insist that financial incentives to communities to support the reintegration of former fighters and communities also support the empowerment and development of women in the communities.

- Make women's meaningful participation in the decision-making bodies a precondition for funding peace, reconciliation, reintegration, and transition processes and programs.

- Ensure the funding for peace, reconciliation, reintegration, and transition processes benefit families, communities, and women rather than individual ex-combatants.

- Urge the Government of Afghanistan to repeal of the Amnesty Law and the Shia Personal Status Law, and to refrain from supporting future laws and policies that violate the Afghanistan Constitution and international human rights commitments.

- Support the GoA and civil society through policy, technical, and financial resources to consult with districts and provinces across the country with discussions on an inclusive NAP on UN SCR 1325 creation process.

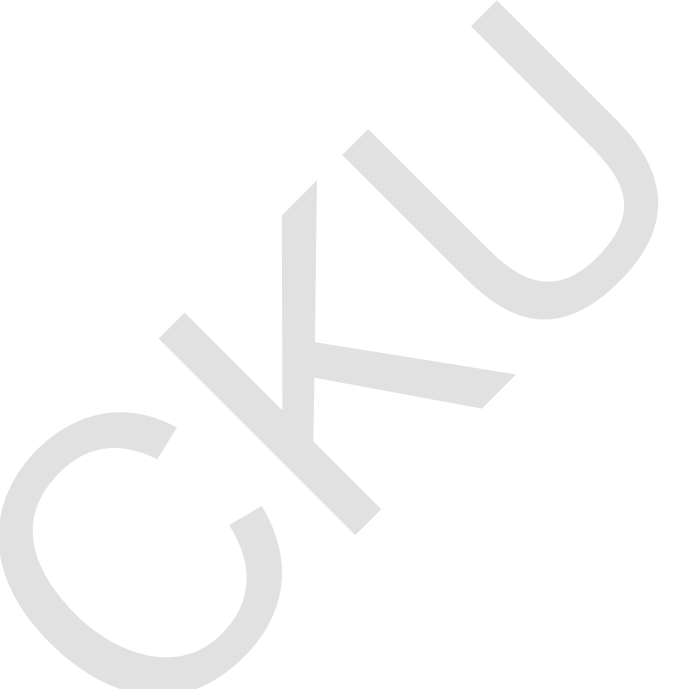

\section{APPENDICES}

\section{Afghanistan Constitution}

Article 22

"Any kind of discrimination and distinction between citizens of Afghanistan shall be forbidden. The citizens of Afghanistan, man or woman, have equal rights and duties before the law"

Article 44

"To create and foster balanced education for women, improve education of nomads as well as eliminate illiteracy in the country, the state shall devise and implement an effective plan"

\section{Article 54}

"Family is the fundamental pillar of the society, and shall be protected by the state. To attain the physical and spiritual health of the family, especially the child and the mother, upbringing of 
children, as well as elimination of related traditions contrary to the principles of the sacred religion of Islam, the state shall adopt necessary measures"

\section{Afghanistan National Development Strategy (ANDS)}

Gender Equity as Cross-cutting

"Enhanced participation of Women in Governance: Fulfillment of the national ac- tion plan for women's rights will be im- plemented and affirmative action programs made available to women."

"The National Action Plan for Women of Afghanistan is being implemented to establishing greater gender equality by eliminating discrimination, building of women's human capital and promoting their participation and leader- ship."

"The ultimate goal is 'gender equality'; a condition where women and men fully enjoy their rights, equally contribute to and enjoy the benefits of development and neither is prevented from pursuing what is fair, good and necessary to live a full and satisfying life[...]The implementation of strategy for gender equity is a shared responsibility among government entities at the national and sub-national levels. MoWA's status as lead ministry for women's advancement will be maintained and strengthened."

\section{Elimination of Violence against Women (EVAW) of Afghanistan}

(As of September 2011, awaiting passage by the Parliament)

Article 2

"This law has the following objectives: 1) Safeguarding the religious and legal rights and protecting the human dignity of women; 2) Protecting well being of family and fighting against customs, traditions and practices that cause violence against women contrary to the provisions of religion of Islam; 3) Protecting the victim of violence (affected woman) or exposed to violence; 4)Preventing violence against women; 5) Ensuring public awareness and education on violence against women; 6 ) Prosecuting perpetrators of violence against women."

\section{Article 3}

"Rape: Perpetrating adultery and pederasty with an adult or under age woman under duress or attack to the chastity and honor of a woman"

\section{Article 5}

"Commission of the following acts shall be deemed as violence against women: 1) Rape; 2) Forcing into prostitution; 3) Recording the identity of victim and publicizing it in a manner that 
damage the personality of victim; 4) Setting into flames, using chemicals or other dangerous substances; 5) Forcing into self-immolation or suicide or using poisonous or other dangerous substances; 6) Causing injury or disability; 7) Battery and laceration; 8) Selling and buying women for the purpose or under pretext of marriage; 9) Baad; [...] 10) Forced marriage; 11) Prohibiting from right of marriage or choosing husband; 12) Marriage before the legal age; 13) Abusing, humiliating, intimidating; 14)Harassment/persecution; 15) Forced isolation; 16) Forcing woman to drug addiction; 17) Depriving from inheritance; 18) Preventing from possession of personal property; 19) Deterring from right to education, work and access to health services; 20) Forced labor; 21) Marrying more than one wife without observing the provision of Article 86 of Civil Code; 22) Denial of relationship."

\section{Amnesty Law}

\section{Article 3}

"All political factions and hostile parties who were involved in a way or another in hostilities before establishing of the Interim Administration shall be included in the reconciliation and general amnesty program for the purpose of reconciliation among different segments of society, strengthening of peace and stability and starting of new life in the contemporary political history of Afghanistan, and enjoy all their legal rights and shall not be legally and judicially prosecuted."

Article 4

\section{Electoral Law}

1) Eligible voters, both men and women, shall be entitled to equal voting right in the elections."

Article 19

"The Wolesi Jirga shall have 249 seats out of which 10 seats are allocated to the nomads and the remaining 139 seats are assigned to the provinces in proportion to their population. Out of the total number of seats for each province, on average, at least two females shall be elected members of the Wolesi Jirga." 